\title{
An Update on the Role of Dietary Phytochemicals in Human Skin Cancer: New Insights into Molecular Mechanisms
}

\author{
Salman Ul Islam ${ }^{1}$, Muhammad Bilal Ahmed ${ }^{1}$, Haseeb Ahsan ${ }^{1,2}$, Mazharul Islam ${ }^{3}$, \\ Adeeb Shehzad ${ }^{4}$, Jong Kyung Sonn ${ }^{1}$ and Young Sup Lee ${ }^{1, *(\mathbb{D})}$ \\ 1 School of Life Sciences, College of Natural Sciences, Kyungpook National University, Daegu 41566, Korea; \\ dr_ssulman@yahoo.com (S.U.I.); muhammad786@knu.ac.kr (M.B.A.); amiable2012@hotmail.com (H.A.); \\ sonnjk@knu.ac.kr (J.K.S.) \\ 2 Department of Pharmacy, Faculty of Life and Environmental Sciences, University of Peshawar, \\ Peshawar 25120, Pakistan \\ 3 Department of Chemical Engineering, College of Engineering, Dhofar University, Salalah 2509, Oman; \\ mazharics@yahoo.com \\ 4 Department of Clinical Pharmacy, Institute for Research and Medical Consultations (IRMC), \\ Imam Abdulrahman Bin Faisal University, Dammam 31441, Saudi Arabia; adeeb.shehzad@gmail.com \\ * Correspondence: yselee@knu.ac.kr; Tel.: +82-53-950-6353; Fax: +82-53-943-2762
}

Received: 26 August 2020; Accepted: 24 September 2020; Published: 25 September 2020

\begin{abstract}
Human skin is continuously subjected to environmental stresses, as well as extrinsic and intrinsic noxious agents. Although skin adopts various molecular mechanisms to maintain homeostasis, excessive and repeated stresses can overwhelm these systems, leading to serious cutaneous damage, including both melanoma and non-melanoma skin cancers. Phytochemicals present in the diet possess the desirable effects of protecting the skin from damaging free radicals as well as other benefits. Dietary phytochemicals appear to be effective in preventing skin cancer and are inexpensive, widely available, and well tolerated. Multiple in vitro and in vivo studies have demonstrated the significant anti-inflammatory, antioxidant, and anti-angiogenic characteristics of dietary phytochemicals against skin malignancy. Moreover, dietary phytochemicals affect multiple important cellular processes including cell cycle, angiogenesis, and metastasis to control skin cancer progression. Herein, we discuss the advantages of key dietary phytochemicals in whole fruits and vegetables, their bioavailability, and underlying molecular mechanisms for preventing skin cancer. Current challenges and future prospects for research are also reviewed. To date, most of the chemoprevention investigations have been conducted preclinically, and additional clinical trials are required to conform and validate the preclinical results in humans.
\end{abstract}

Keywords: skin carcinogenesis; melanoma; UV radiation; dietary phytochemicals; chemoprevention; free radicals

\section{Introduction}

\subsection{Structure of Skin}

Skin represents the largest barrier of the human body to external insults. Histologically, skin is divided into three distinct layers, namely, epidermis, dermis, and hypodermis [1] (Figure 1). In general, skin provides protection from external pressures, serves as a source of percutaneous absorption, and has a significant role in thermoregulation. It is also responsible for the synthesis of macromolecules and aesthetics. The hypodermis consists of subcutaneous fatty tissue along with 
connective tissue. The dermis exhibits vascularity, neuronal ending, receptors (touch, nociception, and proprioception), hair, and glands. The extracellular matrix of the dermis contains connective tissue rich in collagen and elastin. The epidermis is the outer skin layer which is in direct contact with the atmosphere [1,2]. Approximately 80\% of epidermal cells are keratinocytes. Due to its contact with the external environment, these cells undergo continuous wear and tear with constant replacement by newer keratinocytes from the basal epidermal layer. The separation between the epidermis and dermis is through the basement membrane [3]. Other specialized cells in the epidermis include melanocytes (melanin producing), Merkel cells (sensory), and Langerhans cells (immune role). All the cells of the skin perform complex functions, working to achieve and maintain constant homeostasis against various internal and external stimuli. In the case of damage to the skin cells, connective tissue, and other macromolecules, normal processes are dysregulated and give rise to various diseases, including mycoses, inflammatory diseases, and neoplasms [1,4,5].

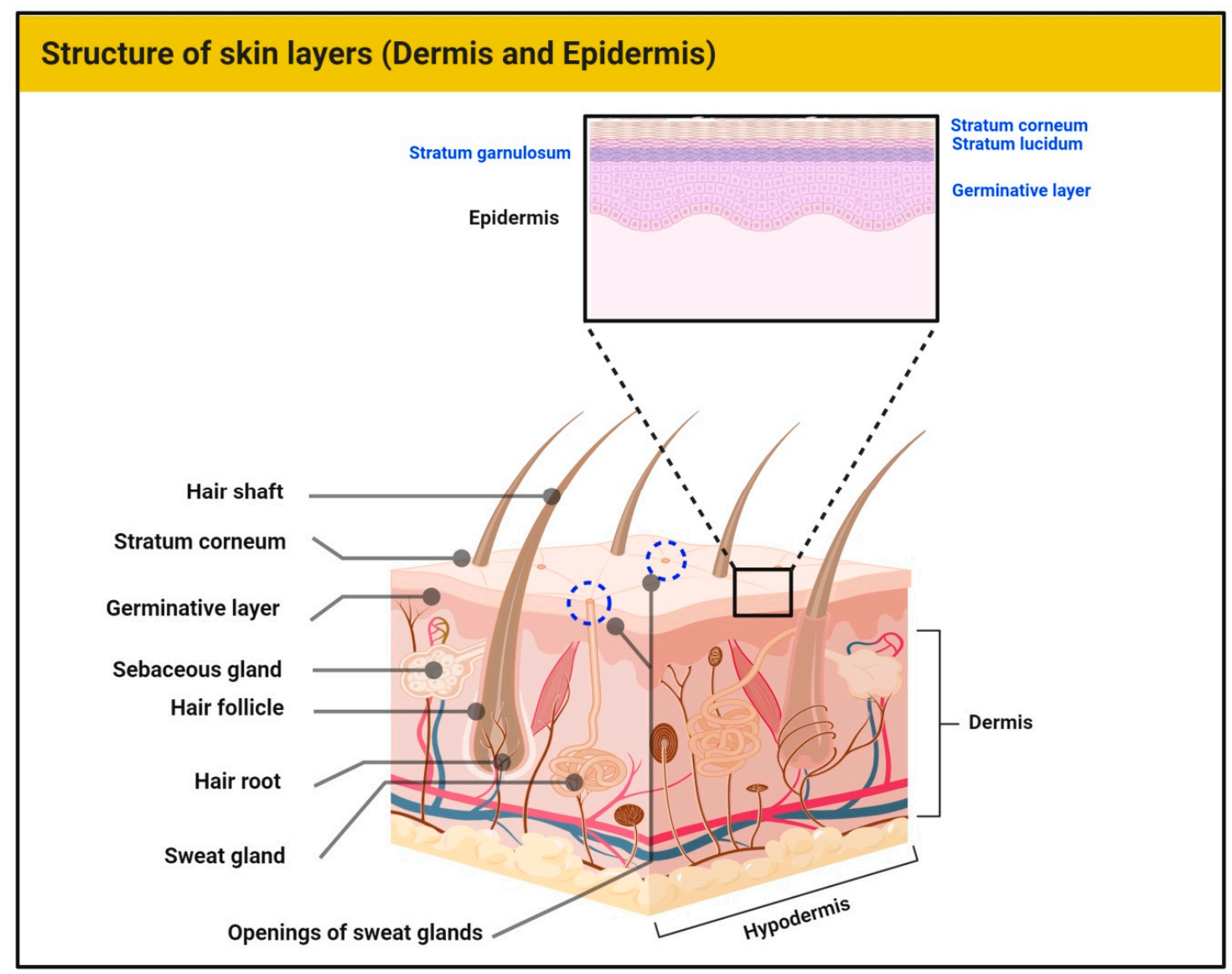

Figure 1. The human skin showing the layers of the epidermis and main structures of the dermis.

\subsection{Skin Carcinogenesis}

Neoplastic development and progression in the skin is a process consisting of three phases: initiation, followed by promotion and progression of tumor cells (Figure 2). The etiology of initiation may be either exogenous (chemicals, virus, ultraviolet (UV) radiation) or endogenous factors (inflammation). Damage caused by these factors to skin cells is irreparable when cells that cannot regain normal function advance to neoplastic progression [6]. Most ultraviolet B (UVB) radiation induces DNA damage that occurs as a transition from $\mathrm{C}$ to $\mathrm{T}$ or $\mathrm{CC}$ to TT in various genes including tumor suppressor gene p53 [7]. Ultraviolet A (UVA) radiation causes mutations via 8-oxodG. These are present as transitions from AT to CG in various genes that regulate cell cycle, apoptosis, and genomic stability (p53) $[7,8]$. Genetic mutation and continuous exposure to UV radiation leads to 
the advancement of initiated cells into the promotion stage [9]. Cells in the initiation stage replicate more vigorously and have less of a tendency to undergo apoptosis [9]. Actinic keratosis (AK) is an example of a precancerous lesion in humans that exhibits extensive mutations when compared with normal human skin cells [10].

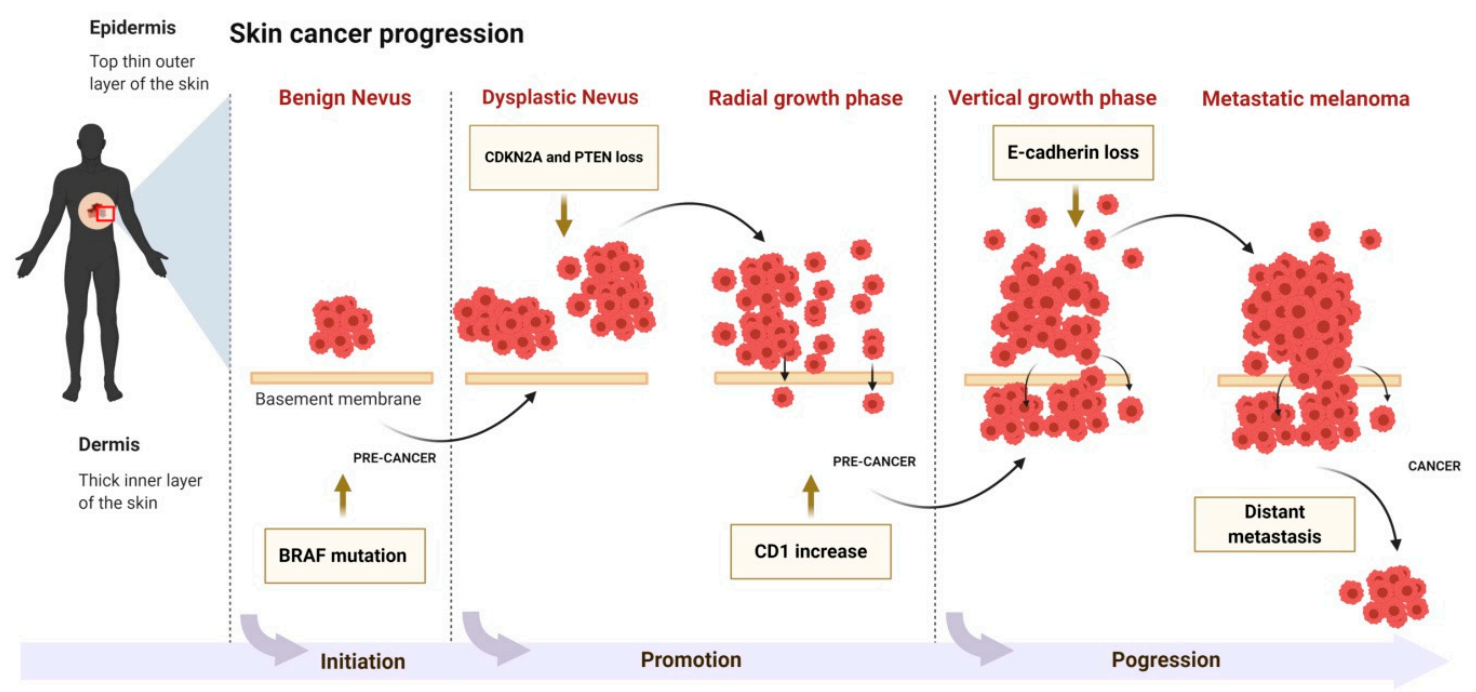

Figure 2. The molecular mechanism of skin cancer progression.

Basal cell carcinoma (BCC), as well as squamous cell carcinoma (SCC), constitute the majority of non-melanoma skin cancers (NMSCs), with Caucasians being affected the most. Both arise from the cancerous transformation of normal keratinocytes [4,8]. Rogers et al. have estimated that approximately two million procedures in about 1.3 million individuals were carried out in 2012, and has increased in recent years [11]. Individuals usually develop invasive NMSCs in later stages of life due to its long latent period, even if the tumor-initiating mutations occurred during childhood. The incidence is less common at a younger age [11,12] and it is more frequent in men [13]. As the fifth most expensive cancer, NMSCs account for the expenditure of billions of dollars in health care and treatment [14]. Usually, patients diagnosed with NMSC die from secondary tumors in the lungs, prostate, or colon resulting from distant metastasis [15]. Therefore, early diagnosis and prompt treatment is highly recommended.

In the United States, most of the reported cases of BCC account for $>3$ million patients annually [11,12]. BCCs exhibit a slower growth rate with a rare chance of metastasis [16], though it does have a tendency to invade surrounding tissues [17]. In the US, SCC remains the second most prevalent skin cancer, accounting for 0.2-0.4 million cases each year. SCC has more of a tendency to metastasize, exhibiting a rate of approximately $4 \%$. The annual number of deaths from metastatic disease is approximately $3000[15,18,19]$. The mortality rate increases in certain cases such as that of immunocompromised individuals [20]. Several studies have explored the transformation mechanism from normal keratinocytes to AK and finally, to SCC. It is believed that a greater period of latency occurs in SCC because AK is resistant to increases in harmful mutations that lead to SCC [10].

The current treatment for NMSCs includes complete eradication of the lesion while preserving the structural and functional architecture of the skin. Current treatment modalities involve surgical intervention including excision, curettage and electrodessication, cryosurgery, micrographic surgery, radiotherapy, and photodynamic therapy. Surgical procedures, such as the Mohs procedure, are preferred to other methods in cases of low-risk lesions [21]. However, the chance of recurrence is high with surgical procedures lacking a complete histological evaluation of the tumor to ensure its entire excision [22]. 


\section{Dietary Phytochemicals for Skin Cancer Therapy}

Dietary phytochemicals are present in plant-based food and exhibit certain nutritional and medicinal value, particularly in preventing various ailments and promotion of human health. Dietary phytochemicals are usually plant secondary metabolites and help proper functioning of human body. Studies have reported approximately 25,000 phytonutrients belonging to different classes of phytochemicals like polyphenols, phenolic acids, flavonoids, diarylalkanoids, carotenoids, lignans, anthocyanins, coumarins, terpenes, and sterols. In addition to various commonly-consumed vegetables and fruits, food items like nuts, beans, tea, and whole grains also contain significant amounts of phytonutrients. Owing to their inherent antioxidative characteristics, these phytonutrients contribute to enhance cardiovascular health, manage the diabetes, and offer cancer chemoprevention [23-25]. Although most dietary phytochemicals do not act like drugs for treating diseases, researchers suggests that their intake can be correlated to a number of positive health outcomes including reduced risk of cancer $[24,26]$. In this review we have covered various classes of dietary phytochemicals mainly in the context of their beneficial role against skin cancer. Our aim is to briefly introduce various aspects of dietary phytochemicals, highlighting their major sources, chemical classes, and major benefits in skin malignancy.

\subsection{Resveratrol (RV)}

$\mathrm{RV}$ is found in a variety of botanical sources such as blueberries, European pine, Arachis hypogea and Reynoutria japonica $[27,28]$ (Table 1). Currently, RV is primarily acquired from red grapes. About $4 \mathrm{mg} / \mathrm{L}$ $\mathrm{RV}$ is found in grape juice [29]. Naturally, RV occurs in the trans- and cis- geometric stereoisomers. Although both isoforms exhibit similar activities, more studies have been conducted on its trans geometric isomer [30].

Table 1. Dietary phytochemicals and their proposed molecular mechanisms in the prevention of skin cancer.

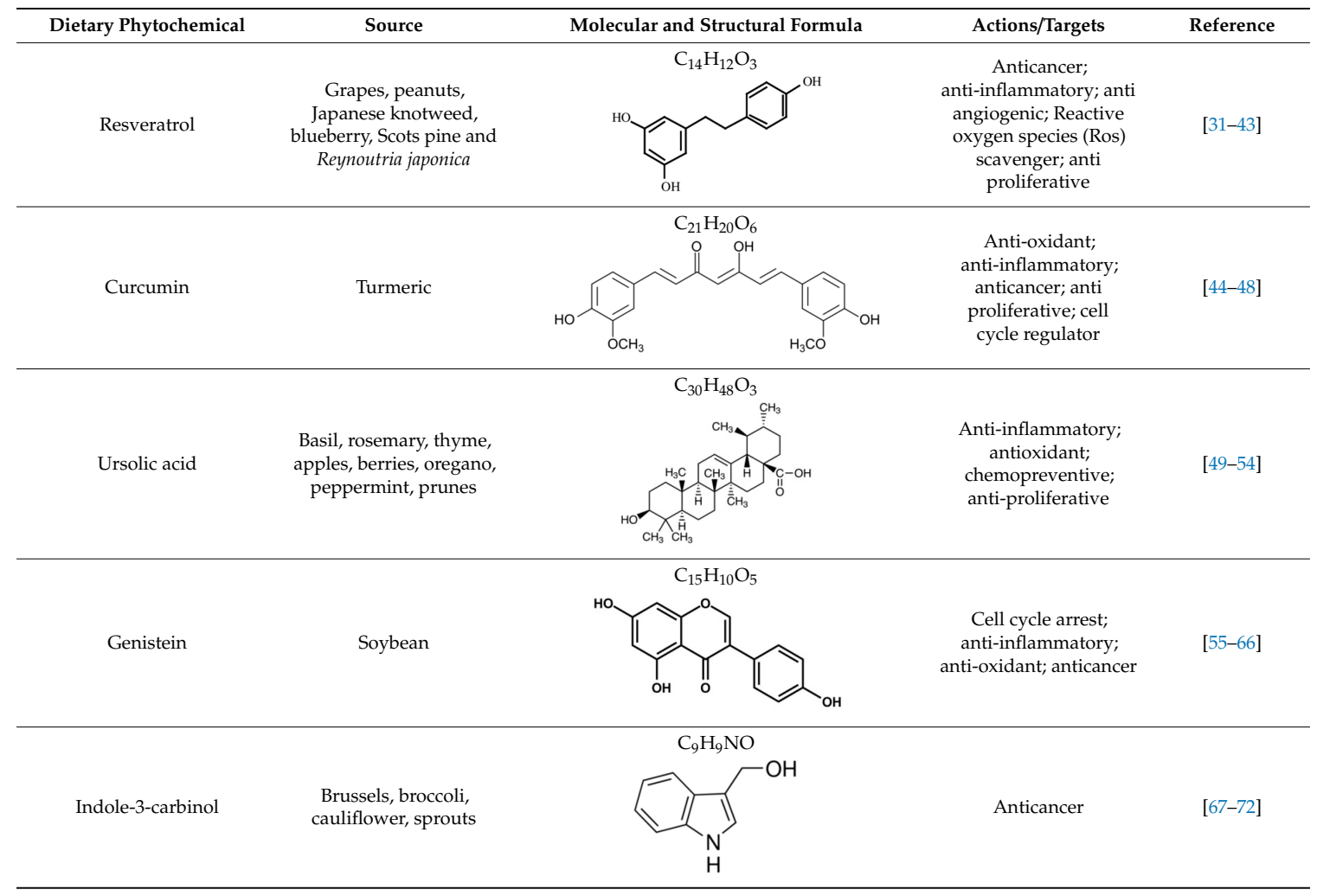


Table 1. Cont.

\begin{tabular}{|c|c|c|c|c|}
\hline Dietary Phytochemical & Source & Molecular and Structural Formula & Actions/Targets & Reference \\
\hline Capsaicin & $\begin{array}{c}\text { Pepperoni, jalapeno, } \\
\text { piri-piri, } \\
\text { habanero peppers }\end{array}$ & $\mathrm{C}_{18} \mathrm{H}_{27} \mathrm{NO}_{3}$ & $\begin{array}{c}\text { Anticancer; } \\
\text { chemopreventive; } \\
\text { anti-inflammatory; } \\
\text { anti-oxidant; } \\
\text { pro-carcinogenic }\end{array}$ & [73-79] \\
\hline Silymarin and silibinin & Milk thistle & Silymarine: $\mathrm{C}_{25} \mathrm{H}_{22} \mathrm{O}_{10}$ & $\begin{array}{l}\text { Liver diseases; } \\
\text { chemotherapeutic; } \\
\text { anticancer; anti } \\
\text { angiogenic; } \\
\text { apoptosis inducer }\end{array}$ & [80-93] \\
\hline Epigallocatechin-3-Gallate & Green tea & & $\begin{array}{l}\text { Anti-inflammatory; } \\
\text { anti-proliferative; } \\
\text { anticancer; anti-oxidant; } \\
\text { anti-erythema }\end{array}$ & [94-101] \\
\hline Eugenol & $\begin{array}{l}\text { Cinnamon, basil, bay } \\
\text { leaves, cloves, nutmeg }\end{array}$ & & $\begin{array}{c}\text { Antioxidant; } \\
\text { anti-proliferative; } \\
\text { Ros scavenger; } \\
\text { anti-inflammatory; cell } \\
\text { death inducer }\end{array}$ & [102-105] \\
\hline Caffeic acid phenethyl ester & Propolis & & $\begin{array}{c}\text { Anticancer; } \\
\text { anti-inflammatory; } \\
\text { immunomodulatory; } \\
\text { anti-oxidant }\end{array}$ & [106-109] \\
\hline Luteolin & $\begin{array}{l}\text { Celery, olives, } \\
\text { carrots, peppers }\end{array}$ & $\mathrm{C}_{15} \mathrm{H}_{10} \mathrm{O}_{6}$ & $\begin{array}{l}\text { Anti-angiogenic; } \\
\text { Apoptosis inducer; } \\
\text { cancer cells } \\
\text { sensitizer; stimulates } \\
\text { melanogenesis; cell } \\
\text { growth inhibitor }\end{array}$ & [110-114] \\
\hline [6]-Gingerol & Zingiber officinale & $\mathrm{C}_{17} \mathrm{H}_{26} \mathrm{O}_{4}$ & $\begin{array}{l}\text { Anti-inflammatory; } \\
\text { anti-oxidant; } \\
\text { Ros scavenger }\end{array}$ & [115-119] \\
\hline Caffeic acid & Coffee, vegetables, fruits & $\mathrm{C}_{9} \mathrm{H}_{8} \mathrm{O}_{4}$ & $\begin{array}{l}\text { Antioxidant; } \\
\text { anti-inflammatory; } \\
\text { anticancer; } \\
\text { anti-migratory; } \\
\text { inhibits EMT }\end{array}$ & [120-128] \\
\hline
\end{tabular}

RV has been reported to exhibit strong anticancer activity, acts as a ROS scavenger, and significantly reduces ROS levels in human skin fibroblasts [32,129]. It has been shown that along with other phytocompounds, RV suppressed tumorigenesis and decreased murine epidermal hyperplasia, while downregulating the expression levels of COX-2, Bcl-2, and p21 [130]. Kowalczyk et al. reported that during treatment of melanoma, RV reduced the viability of skin cancer cells and enhanced the cytotoxic effects of temozolomide [39]. It has also been demonstrated that RV inhibits the activity of redox factor-1, promoting the sensitivity of skin cancer cells to dacarbazine [131] (Figure 3). 


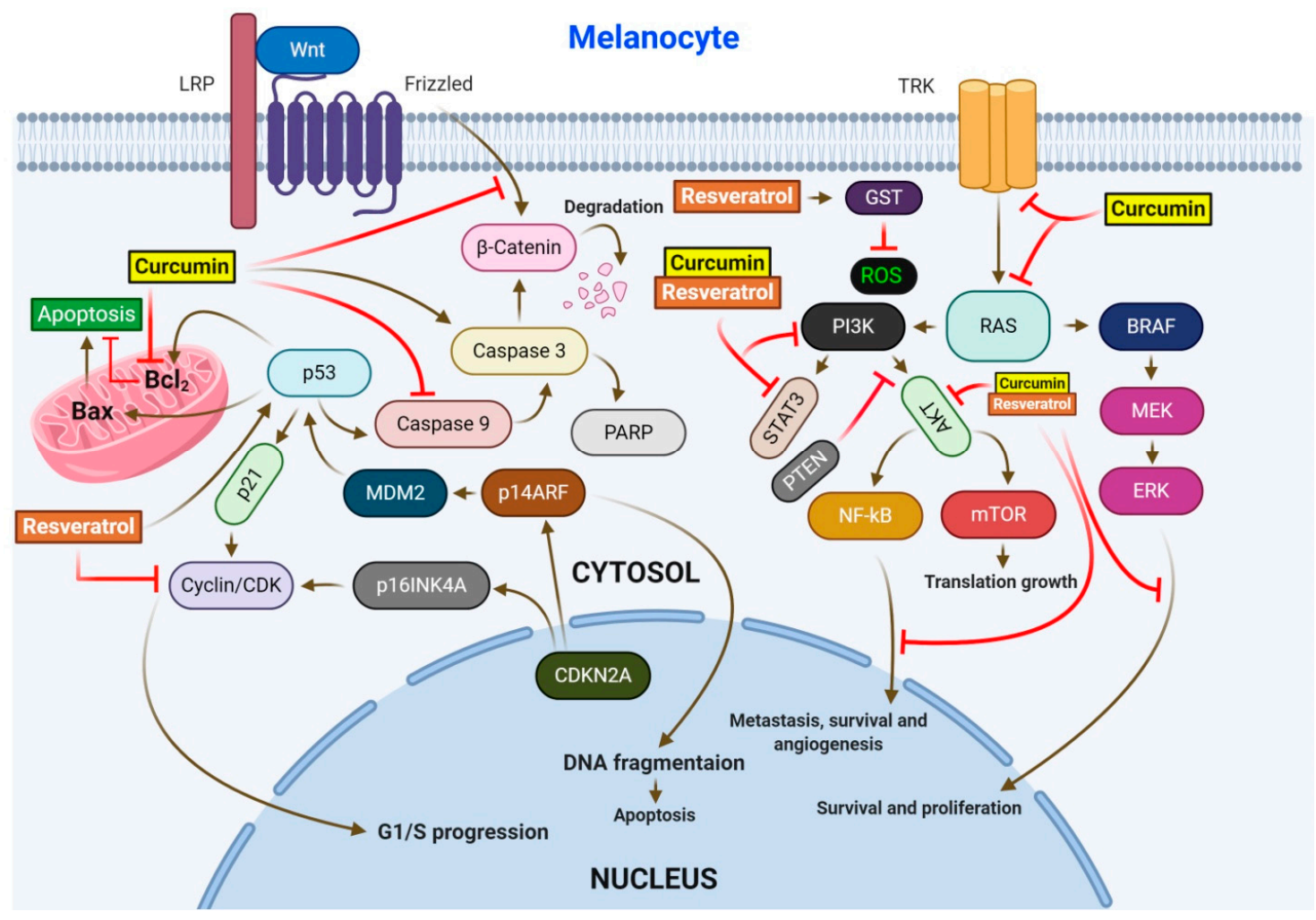

Figure 3. Regulation of the major cell signaling pathways by resveratrol and/or curcumin in melanoma. The four pathways regulated by these drugs include MAPK, PI3K/AKT, WNT/ $\beta$-catenin, and the CDKN2/CDK4 tumor-suppressive pathway. Upon activation, these pathways lead to apoptosis, survival, proliferation, and angiogenesis.

Fuggetta et al. demonstrated that resveratrol exerts anti-melanoma effects both in vitro and in vivo. In this study, $7 \mu \mathrm{g} / \mathrm{mL}$ resveratrol prevented the proliferation of melanoma cells, inducing a 50\% inhibition of cell growth [132]. Additionally, resveratrol inhibited the growth of A431 cells (SCC cells) [133]. Resveratrol induced cell death and downregulated cellular proliferation in FaDu, Cal27 and Det562 cells [134]. Kim et al. demonstrated that a 72-h treatment with $25 \mu \mathrm{M}$ resveratrol decreased the synthesis of DNA [135]. An in vivo investigation revealed that $50 \mathrm{mg} / \mathrm{kg}$ body weight of oral resveratrol resulted in the inhibition of carcinoma cell growth, with over a $50 \%$ reductions in both tumor volume and murine weight [134]. Collectively, these findings suggest that resveratrol exhibits anticancer potential in vitro and in vivo.

Ndiaye et al. showed that because of fast clearance by the liver and intestine, RV exhibits poor bioavailability following oral administration [32]. Therefore, RV fails to stop tumorigenesis when administered orally to skin cancer-bearing mice [36]. Therefore, researchers have turned to topical or parenteral administration routes for RV. Moyano-Mendez et al. demonstrated that RV cream exhibits excellent properties including hydration, luminosity, and elasticity of skin [136]. Another study by Farris et al. demonstrated that RV improved healing of photodamaged skin after 12 weeks when combined with vitamin E and baicalin [136]. Further studies on the benefits and pharmacology of RV are ongoing and will hopefully yield promising results.

\subsection{Curcumin}

Botanical source of curcumin is the rhizome of Curcuma longa. It has been reported in multiple investigations that curcumin possesses remarkable anti-oxidative and anti-inflammatory properties, and exhibits significant therapeutic effects in atherosclerosis, ulcerative colitis, psoriasis, and Crohn's disease [46]. Curcumin also exhibits anticancer activity by interacting and attenuating multiple protein 
targets [137]. A study by Dahmke and coworkers demonstrated the anticancer activity of curcumin against melanoma in mouse model. Curcumin upregulated miRNA-205-5p, a major player in the regulation of cellular proliferation [45] (Figure 3). In another study, curcumin was reported to induce cell death and inhibit proliferation and invasion by upregulating the expression of mmu-miR-205-5p and downregulating Bcl-2, PCNA, and JAK/STAT signaling [138]. Kim et al. demonstrated that curcumin reduces phosphorylation of Akt, S6K, ILGF-1 receptor, IRS-1, and 4EBP in mouse keratinocytes and significantly block chemical-induced skin cancer by DMBA in mice [139]. Zhao et al. reported that curcumin-induced arrest of cell cycle at $\mathrm{G}_{2} / \mathrm{M}$ transition checkpoint in A375 and C8161 cell lines. Curcumin was also found to induce autophagy in the melanoma cell lines. Moreover, curcumin blocked P70S6K activation and caused reduction in the expression of AKT and mTOR [140]. In a study by $\mathrm{Wu}$ et al., curcumin suppressed the STAT3 signaling pathway in A431 cells, leading to a significant reduction in cell invasion [141]. In WM-115 melanoma cells, curcumin stimulated the opening of mPTP, resulting in apoptosis [142]. Chinembiri et al. reported that curcumin inhibited the NF- $\mathrm{kB}$ pro-survival pathway, downregulated Bcl-2 expression, and activated the $\mathrm{p} 53$ tumor suppressor protein, resulting in cell death and inhibition of skin cancer [143].

Gupta et al. [44] studied the effect of curcumin against the SRB12-p9 skin cancer cell line in a mouse model. They demonstrated that oral curcumin at a dose $20 \mu \mathrm{M}$ or higher effectively inhibited SCC growth and decreased the levels of pS6, a well-known downstream biomarker of the mTOR and MEK/ERK signaling pathways. The investigation further demonstrated that curcumin at a concentration of $20 \mu \mathrm{M}$ or higher completely inhibited the proliferation of SRB12-p9 cells. The tolerability and safety of curcumin makes it a valuable phytomedicine for treating skin cancer.

\subsection{Ursolic Acid}

Ursolic acid (UA) is commonly found in basil, rosemary, thyme, apples, berries, oregano, peppermint, and prunes [144] (Figure 4). Studies have demonstrated that UA exhibits strong anti-inflammatory, antioxidant, chemopreventive, and anti-proliferative activity [145]. Several groups have shown that UA induces caspase-mediated apoptosis in melanoma cell lines [51,52]. Additionally, UA has been shown to modulate the G1 phase of the cell cycle by regulating p21WAF1 expression $[49,146]$. Checker et al. reported that UA suppresses the NF- $\mathrm{KB}$ signaling by inhibiting I $\mathrm{B} \alpha$ and $\mathrm{p} 65$ phosphorylation, which further decreases the expression of COX-2 enzymes, cyclin D1, and MMP-9 [147]. Manna et al. reported that, in addition to induction of apoptosis and cell cycle arrest, UA pre-treatment exhibited antioxidant activity in UVB-irradiated human lymphocytes [148]. Researchers are continuing to investigate the anticancer activity of UA, but to date, there have been no human clinical trials conducted in skin cancer. However, Both et al. administered UA liposomes to three healthy subjects and observed increased ceramide content in the skin [54]. Additional large-scale human skin cancer studies are needed to further reveal the molecular mechanism and efficacy of UA-based therapy.

\subsection{Genistein}

Genistein, 4' ,5,7-trihydroxyisoflavone, is an isoflavone compound obtained from soybean [55]. Soybeans rich diets have existed for a long time and used for the treatment of cardiovascular disease, osteoporosis, and malignancies [56]. Studies have enumerated genistein as one of the most abundant phytoestrogens in soybeans and it exhibits potent anti-inflammatory, anti-oxidant, and anticancer effects $[57,58]$. The chemopreventive effects of genistein have been reported in various cancers including neuroblastoma, breast cancer, and non-melanoma and melanoma skin cancers [59]. Several studies have reported that genistein exerts anti-angiogenic effects, induces apoptosis, and decreases metastasis and tumor proliferation in various cancer cell lines [60,61]. In UV-induced sunburn in human, genistein prevented both UV-induced skin cancer and photoaging [62]. Wei et al. reported that genistein pretreatment followed by UVB-exposure in the epidermis of hairless mice prevents UVB-induced oxidative defect [62]. Moore et al. demonstrated the photoprotective characteristics of genistein in 
reconstituted human skin, in which genistein blocked the formation of UVB-induced pyrimidine dimer [149]. Additionally, in xenograft models, genistein (50 $\mu \mathrm{M}$ for four days) exhibited remarkable inhibitory effects against melanoma cells (40.2\% loss of melanoma cells viability), while interfering with the cell cycle, blocking metastasis, and inhibiting tumor growth $[63,150]$. With respect to the underlying molecular mechanism of melanoma cell cycle progression inhibition by genistein, numerous studies have demonstrated that genistein targets p53, p21, and the Chk2 checkpoint kinase [64,65]. In addition to cell cycle regulation, genistein also promotes melanoma cell differentiation by stabilizing protein-linked DNA strand breakage [151,152]. It is necessary to conduct further clinical trials to optimize dosing, route of administration, and evaluate the efficacy of genistein for the prevention of skin cancer.

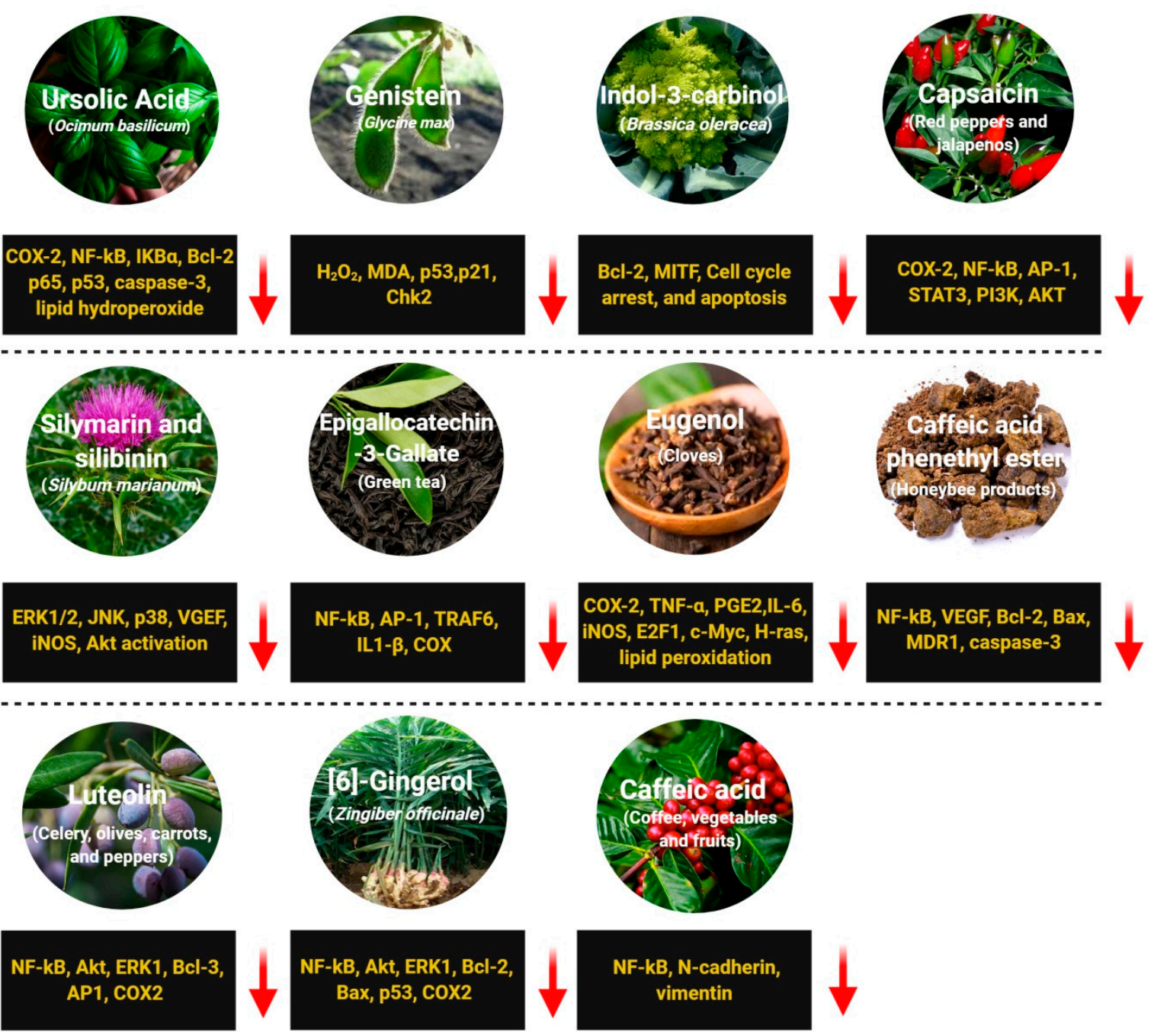

Figure 4. Regulation of various proteins, enzymes, and cellular signaling pathways by dietary phytochemicals in the prevention of skin cancer. Red down arrows indicate downregulation.

\subsection{Indole-3-Carbinol (I3C)}

I3C is a widely distributed member of the Cruciferae family that includes Brussels sprouts, broccoli, and cauliflower [153]. I3C has been reported to show activity against prostate, breast, and lung cancer [69,154-156] Sarkar et al. reported that IC3 $(60 \mu \mathrm{mol} / \mathrm{L})$ and its in vivo dimeric product $3,3^{\prime}$-diindolylmethane $(30 \mu \mathrm{mol} / \mathrm{L})$ showed anticancer potential in prostate cancer cell lines through the regulation of cell cycle, cell proliferation, cell death, and transcriptional activities. It was postulated that the downregulation of NF- $\mathrm{B}, \mathrm{MAPK}, \mathrm{Akt}$, and Bcl-2 signaling were responsible for I3C-induced 
cell death in prostate cancer cells. Additionally, I3C also sensitized the prostate cancer cells to cisplatin (17 nmol/L) treatment [154]. In a similar study, Rahman et al. investigated the actions of I3C in Her-2/neu over-expressing MDA-MB-435 breast cancer cells. This investigations revealed I3C (30-100 $\mu \mathrm{M}$ for 24-72 h) affected the ratio and cellular localization of the Bcl-2 and Bcl-XL (anti-apoptotic proteins) and Bax (pro-apoptotic protein), producing conditions that favour breast cancer cells death [155]. During an investigation regarding the effect of I3C on human lung carcinoma A549 cells, Hee-Sook Choi et al. found that I3C (100-500 $\mu \mathrm{M}$ for $48 \mathrm{~h}$ ) effectively decreased cells proliferation, elevated the formation of apoptotic bodies, and arrested the cell cycle at $\mathrm{G}_{0} / \mathrm{G}_{1}$ phase. Moreover, I3C also enhanced the protein levels of cyclin D1, p21, and p-p53, and upregulated FAs at mRNA levels. The study suggested I3C as a potent therapeutic agent against lung cancer [156]. I3C induced apoptosis and arrest of cell cycle in UVB-sensitized human melanoma cells by downregulating Bcl-2 and MITF [70,71]. Moreover, I3C also inhibited human melanoma cell proliferation by regulating PTE degradation [72]. Using a mouse model, Christensen and LeBlanc showed that I3C (333 of $500 \mathrm{mg} / \mathrm{kg} /$ day) increased chemotherapeutic drug sensitivity [157]. Clinical studies will be required to further prove the safety and efficacy of I3C in skin cancer patients.

\subsection{Capsaicin}

Capsaicin, trans-8-methyl-N-vanillyl-6-nonenamide, is the most popular spice in the world. Capsaicin is a phenolic acid, acting as the key pungent constituent in red chili peppers and provides spiciness to red peppers and jalapenos. There is conflicting evidence as to whether capsaicin is a carcinogen or a chemopreventive agent [73]. Hwang et al. observed a pro-carcinogenic effect of topical capsaicin as it promoted skin carcinogenesis through the activation of EGFR and COX-2 in mice treated with 12-O-tetradecanoylphorbol-13-acetate (TPA) [74]. In contrast, Wang et al. reported that topical capsaicin did not promote the growth of murine skin tumors, and also slightly blocked the formation of papilloma in mice [158]. An investigation correlated the chemopreventive effect of capsaicin to the stimulation of cell death, cell cycle arrest, and decrease of cell proliferation via the inhibition of COX-2, NF- $\mathrm{B}$, AP-1, and STAT3 expression [159]. Moreover, capsaicin has been reported to induce cell death in human cutaneous SCC cells by inhibiting mitochondrial activity [75]. Shin et al. described the potent anti-migratory activity of capsaicin against highly metastatic melanoma cells by the inhibition of Akt and PI3-K signaling [76]. Marques et al. reported that capsaicin synergistically induced apoptosis with HA14-1 in melanoma cells [77]. These findings warrant further intensive studies to clarify the capsaicin role in skin cancer.

To date, there have been no studies describing the topical use of capsaicin in skin cancer. Therefore, we have focused our discussion on the topical use of capsaicin for other ailments. Topical capsaicin has been investigated in multiple double-blind placebo-controlled studies for treating chronic neuropathic or musculoskeletal pain. It was shown that, compared to the placebo, one out of three patients utilizing capsaicin experienced high degree of adverse events such as stinging, erythema, or burning [78]. Therefore, a notable limitation would be for the use of topical capsaicin against skin cancer. Different formulations of capsaicin, with or without other ingredients, may decrease the incidence of local adverse events.

\subsection{Silymarin and Silibinin}

Silibinin, a potent phytochemical, is obtained from milk thistle and is considered the major bioactive molecule in the silymarin complex. Because of poor bioavailability, the application of silibinin has been restricted. To improve absorption, researchers have attempted to develop new formulations in the form of nanosuspensions [80]. Silymarin has been used for the treatment of liver diseases [160]. Additionally, multiple clinical trials have demonstrated the chemotherapeutic potential of silymarin on a variety of cancers including skin malignancy [81]. It has been reported that silymarin exerts chemotherapeutic activity by inhibiting TPA-induced tumors in murine skin. Moreover, silibinin was demonstrated to show strong anticancer activity by targeting the CDK pathway and subsequently 
arresting the cell cycle [82]. During this investigation, researchers found that silibinin inhibited angiogenesis by targeting VEGF receptors and iNOS $[83,89]$. Silibinin has also been shown to trigger caspase-mediated apoptosis through the extrinsic and intrinsic pathways [85,86].

It has been shown that silymarin prevented UV radiation-induced skin cancer in a mouse model of photo-carcinogenesis $[87,161]$. Moreover, silymarin was found to block UVB-induced sunburn, reduce catalase activity, and stimulate the expression of COX and ornithine decarboxylase [88]. Studies have also shown the potential anticancer action of silibinin in targeting the MAPK-mediated signaling cascade $[91,162]$. Mallikarjuna et al. reported that both oral and topical silibinin blocked UV-induced MAPK, p38, JNK, and Akt activity in SKH-1 murine skin [90]. Additionally, it was demonstrated that silymarin remarkably blocked the $\beta$-catenin accumulation in human melanoma cells, which subsequently led to the inhibition of cell migration [93,163]. It can be concluded from these investigations that silymarin and silibinin are effective chemotherapeutic and chemopreventive agents against skin cancer, and additional clinical trials of silymarin with respect to its bioavailability and toxicity are needed.

\subsection{Epigallocatechin-3-Gallate (EGCG)}

EGCG is the major polyphenol compound from green tea. EGCG is the most famous anti-oxidant, anti-inflammatory, and anti-proliferative polyphenol among the green tea phenols [101]. An investigation reported that anti-inflammatory potential of EGCG were correlated with the suppression of COX and lipoxygenase activity, which lowered skin tumor burden and reduced hyperplasia and epidermal edema [101,164]. A study reported that, in human skin, topical EGCG blocked UV-induced nitric oxide and hydrogen peroxide in both the epidermis and dermis [101]. Such a reduction may be linked to the downregulation of MAPK signaling pathways [165]. Others have suggested that anti-proliferative mechanisms include the regulation of NF- $\mathrm{KB}, \mathrm{AP}-1$, angiogenesis, and cytotoxic T cells $[99,100,166]$.

A study reported that EGCG sensitized skin cancer cells to interferon-induced growth inhibition, reduced the proliferation of cells, and induced apoptosis [98]. Furthermore, it was noted that concomitant treatment of EGCG with interferon showed strong effect than either agent alone. The possible underlying mechanisms demonstrated by this study include downregulation of inflammasome and NF- $\mathrm{KB}$ activity, which decreased interleukin- $1 \beta$ secretion and tumor growth, respectively [97]. Zhang et al. reported that EGCG inhibited the migration and invasion of melanoma cells by abolishing TRAF6 activity [96].

EGCG has undergone several small human trials for skin cancer chemoprevention. Currently, an important issue under consideration is oral versus topical administration of EGCG. It was shown in a study that green tea constituents administered to mice through oral or parenteral routes effectively inhibited UV-induced skin papilloma [167]. In contrast, an investigation demonstrated that tumor reducing outcomes in mice were obtained only by topical EGCG, whereas oral administration was ineffective [168]. It has been postulated that the discrepancy between the topical and oral administration of EGCG is due to inadequate EGCG supply to the skin after oral ingestion. An investigation confirmed the protective activities of topical green tea phenols against UV radiation-induced erythema in a cohort of human volunteers [169]. Furthermore, it was demonstrated in a single-blind, randomized clinical trial of 50 volunteers that, compared to the placebo group, supplementation of oral green tea extract with vitamin C did not exhibit effectively decreased leukocyte infiltration or skin erythema [170]. During a double-blind phase II randomized clinical trial, 51 volunteers with AK were administered topical EGCG for 12 weeks. The researchers did not find any significant difference between the EGCG and placebo groups at the end of the investigation. It was postulated from the trial that topical EGCG, possibly because of poor bioavailability, may not have been active in the formulation [152]. Collectively, it may be concluded that for skin cancer prevention, topical ECGG is more effective compared with an oral formulation. However, the optimal formulation for topical EGCG requires further investigation. 
Moreover, EGCG role, as a potential synergistic treatment for skin cancer, remains another important area for further study.

\subsection{Eugenol}

Eugenol is a phenolic compound which is abundantly found in cinnamon, basil, bay leaves, cloves, and nutmeg. Eugenol may be administered at different dosages through various routes. It exhibits antioxidant and anti-proliferative activities through different mechanisms. For example, as an antioxidant, eugenol inhibits ROS formation and lipid peroxidation [171]. Moreover, topical eugenol blocks the inflammatory response by regulating various proinflammatory molecules including COX-2, PGE 2 , iNOS, IL-6, TNF- $\alpha$, and NK-кB [102]. Pal et al. demonstrated that topical and oral eugenol decreased the incidence of papilloma development in mice [104]. Another study showed that eugenol downregulates the c-Myc and H-ras genes, modulates the levels of p53, and stimulates cell death by decreasing E2F1 synthesis [103,104].

Esmaeili et al. formulated a $2 \%$ nanoemulsion of eugenol for topical use, which at $1.5 \mathrm{~h}$, demonstrated superior anti-inflammatory activity compared with topical piroxicam [105]. Additional skin permeation investigations will be required to understand the anti-inflammatory, antioxidant, and anticancer activities of eugenol as well as for the development of more potent formulations.

\subsection{Caffeic Acid Phenethyl Ester (CAPE)}

CAPE is the major bioactive molecule of propolis, which is obtained from honeybee products. Multiple studies have reported the in vitro and in vivo anticancer potential of CAPE against various cancers including lung cancer, colon cancer, glioma, pancreatic cancer, breast cancer, hepatocellular carcinoma, gastric cancer, cholangiocarcinoma, and melanoma [107-109,172-176]. A study reported the anticancer, anti-inflammatory, and immunomodulatory effects of CAPE in vitro [177]. CAPE effectively blocked TPA-induced skin papilloma in mice. VEGF and MDR-1 levels were downregulated upon CAPE treatment. CAPE also regulated cell cycle and cell death via NF- $\mathrm{B}$ [106]. Chen et al. reported that CAPE attenuated the expressions of $\mathrm{Bcl}-2, \mathrm{Bcl}-2$, and caspase-3 in leukemia cell lines, which subsequently led to cell death [178]. Yordanov et al. also showed that CAPE exhibits antioxidant effects on murine skin at lower doses [179]. In short, CAPE may act as a chemopreventive agent for skin cancer, however, clinical trials are required to verify the overall efficacy.

\subsection{Luteolin}

Luteolin is abundant in celery, olives, carrots, and peppers. Studies have demonstrated that luteolin exhibits anticancer activity through various molecular mechanisms including angiogenesis inhibition, caspase-mediated apoptosis, and by sensitizing cancer cells to anticancer drugs [114]. Luteolin has been found to stimulate melanogenesis and decrease the aggressiveness of skin cancer cells through regulation of the $\beta 3$-integrin and focal adhesion kinase signaling cascade [113,180]. Studies have shown that luteolin induces cell death and prevents cancer cell growth by regulating Bax, Bcl-2, and ERK1/2 signaling [110,111]. These findings suggest the luteolin may be a potent anticancer molecule, however, additional investigations are needed to better understand the efficacy and pharmacology of luteolin.

\subsection{2. [6]-Gingerol}

[6]-Gingerol, a pungent phenol, is obtained from the roots of the Zingiber officinale ginger plant. Approximately two decades ago, Park et al. demonstrated that [6]-gingerol significantly inhibits skin papilloma formation [181]. Subsequent studies have shown that [6]-gingerol lowers the activity of epidermal ornithine decarboxylase, inhibits COX-2, and downregulates the activation of NF- $\mathrm{kB}$ by modulating MAPK activity [115,181]. Moreover, [6]-gingerol exhibits antioxidant action by decreasing UV-induced ROS generation, activation of Fas as well as caspase-3, -8, and -9 levels [116]. Other possible molecular mechanisms are the modulation of AP-1 DNA binding potential and regulation of survival 
factors such as Bcl-2, Bax, and p53 [117,118]. To date, there are no published human trials regarding the topical use of [6]-gingerol. Efforts have been made to incorporate [6]-gingerol into solid lipid nanoparticles with improved chemical stability for topical use, which may provide a feasible and stable option for evaluating efficacy [119].

\subsection{Caffeic Acid (CA)}

CA is widely distributed in coffee, fruits, and vegetables. CA is a polyphenolic bioactive compound exhibiting remarkable antioxidant, anti-inflammatory, and anticancer activities [120,121]. A study reported that, in keratinocyte cells, CA effectively inhibited colony and EGF-induced tumor formation [124]. Furthermore, it has been shown that CA reduced the cancer stem cells migration cancer stem cells by enhancing the phosphorylation of $\mathrm{p} 38$ and inhibiting NF- $\mathrm{kB} /$ snail signaling. It was further demonstrated that 38 blocked the binding potential of NF- $\mathrm{kB}$ to the promoter of the snail gene, resulting in inhibition of snail expression. Additionally, CA treatment prevented the epithelial-mesenchymal transition (EMT) in human keratinocyte tumors, which was evident from increased levels of E-cadherin, whereas $\mathrm{N}$-cadherin and vimentin levels were downregulated. These studies reveal that $\mathrm{CA}$ plays a role in preventing the invasion and migration of cancer cells $[105,124]$. Researchers remain optimistic for the development of new formulations of CA for skin cancer treatment.

\section{Role of Whole Fruits and Vegetables in Skin Cancer Prevention}

Fruits and vegetables have high nutrient content. Whole fruits can be fresh, dried, canned, or frozen. Dieticians recommend that fruits should be ingested whole or in $100 \%$ pure juice form, which preserves their nutrient-dense nature [182]. Studies have shown that fruits contain various phytonutrients with anti-carcinogenic, anti-mutagenic, antioxidant, and anti-inflammatory properties [183-186]. Here, we discuss the benefits whole fruits and vegetables in the context of skin cancer. This section includes multiple in vitro and in vivo studies on the effects of whole fruit and fruit extracts against skin cancer (Figure 5).

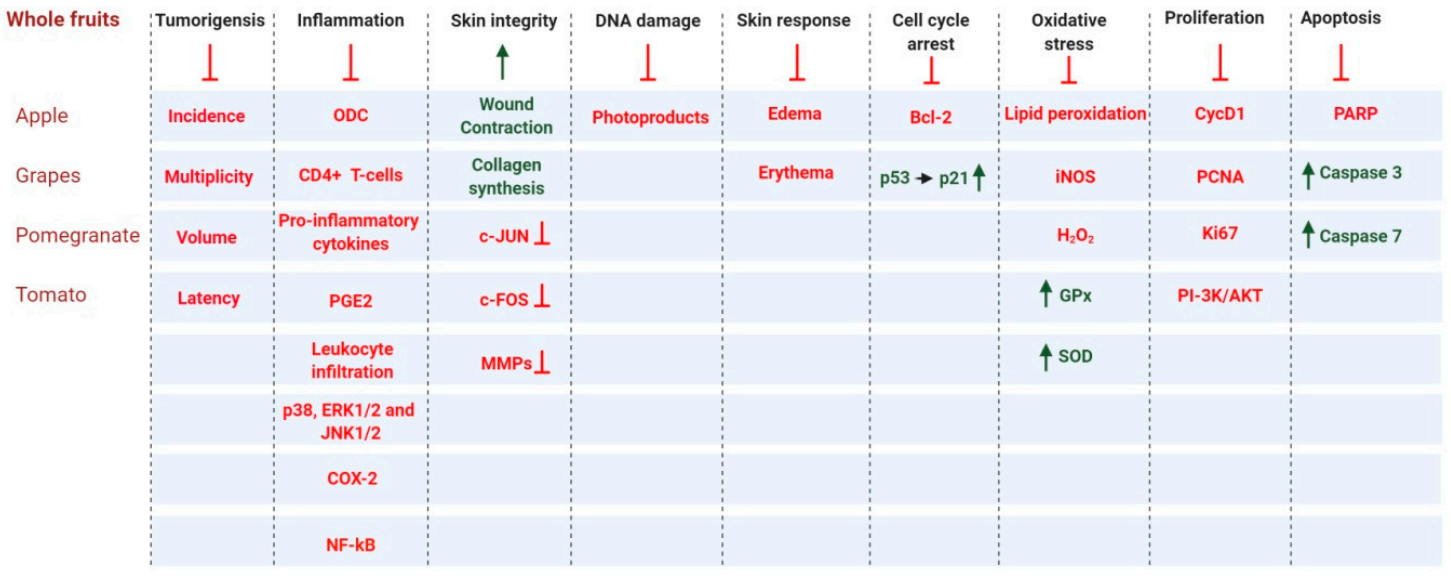

Figure 5. Whole fruit and vegetable products contribute to the prevention of skin carcinogenesis by regulating a broad range of cell signaling pathways. Arrows and dark green text indicate activation and/or upregulation, and red lines with a blunt end and red text indicate inhibition and/or downregulation.

\subsection{Apple (Malus pumila)}

Apples are one of the largest sources of fruit phenolics in the United States [187]. Apple skin contains more phenolic content compared with the remainder of the fruit [188]. The apple flesh contains caffeic acid, procyanidins, and catechins, whereas the peel contains all of these plus quercetin glycoside [188]. Ding et al. conducted a study to determine the chemopreventive effects of fresh apple 
peel extract against DMBA-TPA-induced skin tumorigenesis in a transgenic mouse model. Mice were given apple peel extract for two days in drinking before starting a dose of DMBA, and then continued till the end of the investigations [189]. The mice were sacrificed after 20 weeks of biweekly TPA application. The mice ingesting the apple peel extract exhibited a greater than $50 \%$ inhibition in the number of papillomas, accompanied by a decrease in tumor volume [189]. This study further revealed that the reduction of tumorigenesis was relative to a concomitant decrease of ROS and regulations of MAPK and AP-1 [189]. George and Rupasinghe tested the effect of a flavonoid-rich ethanolic extracts of the Northern Spy apple cultivar against carcinogen-induced toxicities in normal human bronchial epithelial cells. The apple flavonoids reduced total ROS generation, blocked carcinogen-induced oxidative DNA damage, and facilitated DNA repair mechanisms [190]. To date, very few studies, mostly in vitro, are available in this area and additional investigations in animal models and humans will be necessary (Table 2).

Table 2. Experimental approaches to analyze the effects of fruits and vegetables on skin cancer.

\begin{tabular}{|c|c|c|c|c|}
\hline \multicolumn{5}{|c|}{ In Vitro Approaches } \\
\hline Constituent & $\begin{array}{l}\text { Major Constituents and Their Chemical and } \\
\text { Structural Formula }\end{array}$ & Dose & Experimental Approach and Results & Reference \\
\hline Apple peel extract & $\begin{array}{c}\text { Quercetin-3-O- } \beta \text {-d-glucopyranoside } \\
\left(\mathrm{C}_{21} \mathrm{H}_{20} \mathrm{O}_{12}\right) \\
\mathrm{O}_{\mathrm{OH}}^{\mathrm{H}}\end{array}$ & $1: 10-1: 640$ & $\begin{array}{c}\mathrm{JB} 6 / \mathrm{AP} / \mathrm{kB} \\
(50 \% \text { inhibition in the number of } \\
\text { papillomas, accompanied by a decrease in } \\
\text { tumor volume })\end{array}$ & {$[189,191]$} \\
\hline $\begin{array}{l}\text { Pomegranate } \\
\text { extract }\end{array}$ & $\begin{array}{c}\text { Delphinidin-3,5-diglucoside } \\
\left(\mathrm{C}_{29} \mathrm{H}_{35} \mathrm{ClO}_{17}\right) \\
\mathrm{cr}\end{array}$ & $10-40 \mu \mathrm{g} / \mathrm{ml}$ & $\begin{array}{c}\text { HaCaT cell lines } \\
\text { (photoprotective activity against } \\
\text { UVB-induced skin damage) }\end{array}$ & {$[192,193]$} \\
\hline $\begin{array}{l}\text { Pomegranate } \\
\text { extract, oil, or juice }\end{array}$ & $\begin{array}{l}\text { Delphinidin-3,5-diglucoside } \\
\left(\mathrm{C}_{29} \mathrm{H}_{35} \mathrm{ClO}_{17}\right)\end{array}$ & $\begin{array}{l}\text { 5-10 } \mu \mathrm{g} \text { (extract), } 0.1 \\
\mathrm{~mL} / \text { well (oil), } 1-2 \mu \mathrm{L} \text { (juice) }\end{array}$ & $\begin{array}{c}\text { Reconstituted human skin (epidermTM } \\
\text { FT-200) } \\
\text { (protective effect on UVB-mediated } \\
\text { damage) }\end{array}$ & {$[193,194]$} \\
\hline \multirow[t]{2}{*}{ Grape seed extract } & $\begin{array}{l}\text { Catechin } \\
\left(\mathrm{C}_{15} \mathrm{H}_{14} \mathrm{O}_{6}\right)\end{array}$ & $10-40 \mu \mathrm{g} / \mathrm{ml}$ & $\begin{array}{c}\text { HaCaT cell lines } \\
\text { (photochemopreventive action against } \\
\text { UVB-induced skin cancer) }\end{array}$ & [195-197] \\
\hline & \multicolumn{4}{|c|}{ In Vivo Approaches } \\
\hline Constituent & $\begin{array}{l}\text { Major Constituents and Their Chemical and } \\
\text { Structural Formula }\end{array}$ & Dose & Experimental Approach and Results & Reference \\
\hline \multirow{2}{*}{ Apple peel extract } & $\begin{array}{l}\text { Quercetin-3-O- } \beta \text {-d-glucopyranoside } \\
\qquad\left(\mathrm{C}_{21} \mathrm{H}_{20} \mathrm{O}_{12}\right)\end{array}$ & $\begin{array}{l}\text { oral, in lieu of drinking } \\
\text { water and topical } \\
\text { application, } 6 \times \text { daily }\end{array}$ & $\begin{array}{l}\text { AP-1 luciferase reporter transgenic mice } \\
\text { (C57BL/ } 6 \times \text { DBA2) } \\
(50 \% \text { inhibition in the number of } \\
\text { papillomas, accompanied by a decrease in } \\
\text { tumor volume) }\end{array}$ & \multirow[b]{2}{*}[189,191]{} \\
\hline & & $\begin{array}{l}\text { oral, in lieu of drinking } \\
\text { water, } 48 \mathrm{~h} \text { prior }\end{array}$ & $\begin{array}{l}\text { AP-1 luciferase reporter transgenic mice } \\
\text { (C57BL/ } 6 \times \text { DBA2) } \\
(50 \% \text { inhibition in the number of } \\
\text { papillomas, accompanied by a decrease in } \\
\text { tumor volume) }\end{array}$ & \\
\hline \multirow{4}{*}{$\begin{array}{l}\text { Pomegranate fruit } \\
\text { extract }\end{array}$} & \multirow{4}{*}{$\begin{array}{c}\text { Delphinidin-3,5-diglucoside } \\
\left(\mathrm{C}_{29} \mathrm{H}_{35} \mathrm{ClO}_{17}\right) \\
\end{array}$} & $2 \mathrm{mg}$ (topical), $30 \mathrm{~min}$ prior & CD-1 (anti-tumor; anti proliferative; & \multirow{4}{*}[193,198-201]{} \\
\hline & & $2 \mathrm{mg}$ (topical), prior to TPA & anti-migratory effects) & \\
\hline & & $\begin{array}{l}0.2 \% \text { in drinking water, } 14 \\
\text { days prior }\end{array}$ & \multirow{2}{*}{$\begin{array}{l}\text { SKH-1 hairless mice } \\
\text { (anti-tumor; anti proliferative; } \\
\text { anti-migratory effects) }\end{array}$} & \\
\hline & & $\begin{array}{l}0.2 \% \text { in drinking water, } 14 \\
\text { days prior up to the end of } \\
\text { treatment }\end{array}$ & & \\
\hline
\end{tabular}


Table 2. Cont.

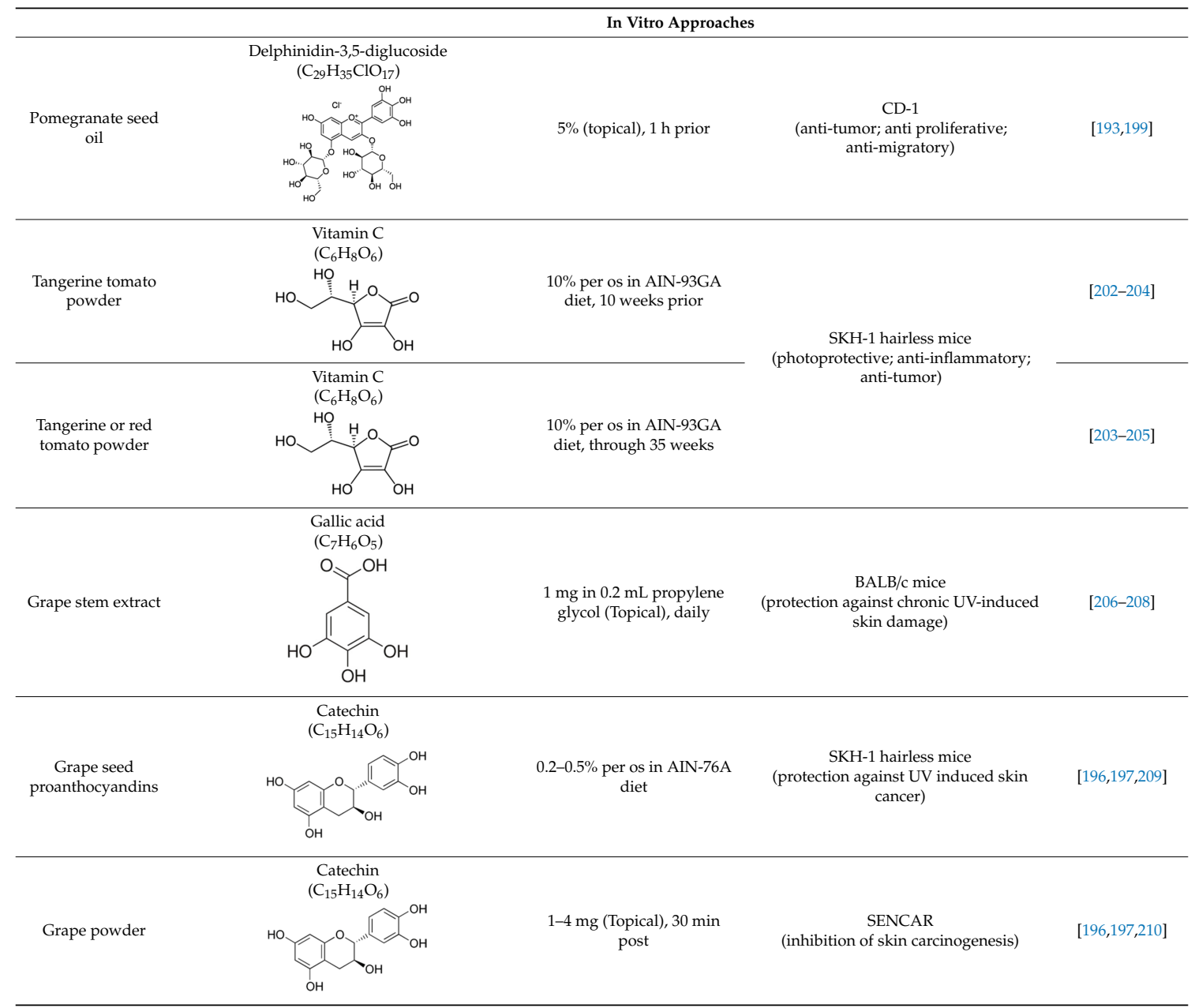

\subsection{Pomegranate (Punica granatum)}

Pomegranate fruit contains both types of true tannins: anthocyanins (condensed tannins) and hydrolyzable tannins $[198,211]$. Its effect on skin diseases including cancer have been studied by several research groups. The administration of pomegranate fruit extract (PFE) via a topical route $(2 \mathrm{mg}$ in acetone) to CD-1 mice, followed by TPA application at a dose of $3.2 \mathrm{nmol} / \mathrm{mouse}$ after $30 \mathrm{~min}$, resulted in the inhibition of the TPA-induced inflammatory response [199]. A reduction in skin erythema, swelling, and COX-2 activity was also observed. Furthermore, a reduction in MAPK signaling was evident. PFE inhibited tumor growth initiated and promoted in CD-1 mice by DMBA and TPA, respectively. The latency period of the tumor was extended and approximately $20 \%$ of the PFE-treated animals remained tumor-free [198]. This study demonstrates the protective effects of PFE against inflammation, and tumor development and progression. Similarly, antineoplastic effects were observed by Hora et al. In mice that were administered 5\% pomegranate seed oil [199]. Gil et al. induced skin damage in SKH-1 hairless mice by UVB radiation. In one dosing schedule, PFE was administered in drinking water for 14 days prior to a single dose of radiation, whereas in another dosing schedule, radiation exposure was given on alternate days for seven days. PFE caused a reduction in skin edema, leukocyte migration at the inflammatory site, cell proliferation, and COX-2 expression. Using the first dosing schedule, PFE-treated mice exhibited increased expression of p53 and p21 accompanied by enhanced repair of CPDs and 8-oxodG. A lower proliferative index was observed with both dosing schedules as determined by expression of the proliferating markers, PCNA [200,201] and cyclin D1 [201]. UVB radiation also increased the activation of NF-kB. The study with the second dosing schedule also evaluated the upstream proteins responsible for activating MAPK and NF-KB [200,201] 
and it was found that PFE reduced the expression of ERK1/2, JNK1/2, and p38. Therefore, PFE exerts its protective effect by attenuating multiple intracellular signalling pathways involved in various cellular processes including survival, proliferation, apoptosis, and the inflammatory response [201]. Pomegranate juice and oil have also been evaluated for their protective effects. Studies have revealed photoprotective activity against UVB-induced skin damage in NHEK [212], HaCaT keratinocytes [192], and human skin (reconstituted) [194]. PFE has also been found to inhibit the phosphorylation of c-Jun and c-Fos, thereby rendering them inactive. PFE inhibits MMP protein and c-Jun, c-Fos, and MMPs are involved in the breakdown of collagen in connective tissue [192,194]. Overall, these studies establish a protective role for pomegranate in inflammation and skin cancer.

\subsection{Tomato (Solanum lycopersicum)}

An abundance of carotenoids in tomato has been attributed to its skin protective effects. Lycopene, the major carotenoid found in tomatoes, was reported to function as a free radical scavenger [213]. Stahl and co-workers have suggested that lycopene, along with other carotenoids and noncarotenoids in tomatoes, are responsible for eliciting photoprotective effects against UV radiation [214]. Kopec et al. examined the photoprotective effects of tomato in a gender-based manner. SKH-1 hairless mice were exposed to UV-mediated skin damage followed by an evaluation of the effects of tomato. UVB exposure was applied in a single dose whereas tomatoes were provided for 10 weeks. The results indicated that the levels of carotenoids in skin and blood were higher in female mice. With respect to the photoprotective mechanism, UVB-induced carotenoids were associated with a reduction in inflammation and CPDs [202]. In a study by Cooperstone et al., mice were provided with a tomato-containing diet for 35 weeks. The mice were exposed to radiation three times a week at a dose of $2240 \mathrm{~J} / \mathrm{m}^{2}$. In male mice, papilloma were produced at 6-10 weeks compared with 10-12 weeks for the female mice. Interestingly, it was observed that male mice treated with a tomato diet exhibited a lower number of tumors compared with the control group, whereas no differences were observed in the female cohort [205]. These results are encouraging, but further investigations are needed to analyze the photoprotective effects of tomato constituents in other in vitro and in vivo models.

\subsection{Grape (Vitis vinifera)}

Filip et al. used extracts from grape seeds to determine its protective effects against UVB radiation. The extracts ( $4 \mathrm{mg} / \mathrm{cm}^{2}$ per mouse) were topically applied $30 \mathrm{~min}$ before a single dose of $20 \mathrm{~mJ} / \mathrm{cm}^{2}$ UVB radiation to female SKH-1 hairless mice. The extract was found to reduce lipid peroxidation, nitric oxide, and reduced the activity of caspase-3. Hence, the seeds were effective in reducing oxidative stress induced by UVB radiation [215]. In another study, grape seed extracts were analyzed for their photoprotection by increasing UVB exposure continuously for 10 days at a dose of $240 \mathrm{~mJ} / \mathrm{cm}^{2}$. The extract was found to reduce CPDs, cell proliferation (hyperplasia), cytokine release (inflammation), and oxidative stress [216]. Jang et al. used grape stem extracts to determine the effects against UV-induced skin damage. C57BL mice were given UVB radiation doses three times a week for three weeks at dose of $120 \mathrm{~mJ} / \mathrm{cm}^{2}$. Extracts were provided for one week before irradiation and continuously throughout the duration of the study. The observed effects included a reduction in lipid peroxidation, reduced neutrophil and mast cell migration to the site of exposure, and reduced COX-2 expression [217]. In a study by Cho et al., a reduction in oxidative stress was observed through increased activity of glutathione peroxidase and superoxide dismutase. In addition, the skin architecture was preserved and DNA damage was also prevented. The duration of UVB radiation was three times a week for one month in male Balb/c mice and the extracts from Muscat bailey A grape were applied topically. A reduction in the inflammatory response was also observed as evidenced by reduced leukocyte migration and reduced proinflammatory cytokine production [206]. In a study by Perde-Schrepler, immortalized $\mathrm{HaCaT}$ keratinocytes were treated with a Burgund mare variety of red grapes. A protective effect against UV radiation $\left(25-300 \mathrm{~mJ} / \mathrm{cm}^{2}\right)$ was observed at concentrations of $10-20 \mu \mathrm{g} / \mathrm{mL}$. An increase in skin viability and a reduction in apoptosis, lipid peroxidation, and DNA damage were observed [195]. 
Kobayashi et al. evaluated the effects of $Y$ grape juice and its fractional extract in ethyl acetate on six-week-old SENCAR mice. Edema was induced using TPA, whereas carcinogenesis was induced with DMBA. Topical and oral treatment with the extracts reduced edema, whereas DMBA-TPA induced carcinogenesis was reduced to significant extent as evidenced by decreased tumor number, tumor incidence, and COX-2 action [218]. An investigations reported a different treatment protocol in a similar mouse model. The treatment plan included initial pre-treatment with resveratrol followed by the administration of freeze-dried grape powder (GP) or continued oral administration of GP in AIN-93G diet for a period of two weeks before chemical induction of tumors. After 12 weeks, both treatments reduced tumor number, COX-2 expression, and DNA damage [210]. Since $90 \%$ of skin cancers are linked to UV rays, chemically-induced tumors are less significant [209]. In another study of UV induced tumors in SKH-1 female mice, grape seed (rich in proanthocyanidins) was evaluated for its protective effects. The dose and duration of radiation was $180 \mathrm{~mJ} / \mathrm{cm}^{2}$ three times a week for 24 weeks. A reduction in radiation-induced inflammatory mediators and COX-2 expression was observed [219]. Singh et al. subjected SKH-1 female mice to $180 \mathrm{~mL} / \mathrm{cm}^{2}$ of UVB rays twice a week for 28 weeks. The diet included a 0,3 , or $5 \%$ concentration of freeze-dried GP. The diet resulted in increased apoptosis and reduced lipid peroxidation and proliferative markers [220]. The treatment also increased NER-facilitated repair of the skin by reducing the level of CPDs [220]. Overall, grapes and their components exert promising activity as naturally-occurring anti-inflammatory and anti-neoplastic agents.

\section{Limitation, Safety Consideration, and Future Prospects of Dietary Phytochemicals}

Dietary phytochemicals have experienced many challenges including low bioavailability. In our daily diet, we consume a significant amount of these phytochemicals. They are readily digested and eliminated by our body, resulting in a short-lived pharmacologic window [221]. Researchers are striving to develop new approaches that will increase the stability of dietary phytochemicals. Noteworthy strategies include the development of a stable dosage form of dietary phytochemicals, such as microparticles or nanoparticles, exhibiting increased stability and antioxidant properties [222]. Iqbal et al. demonstrated that EGCG showed increased stability and high absorption in the intestine when green tea extract was coated with chitosan [223]. Yadav et al. observed enhanced stability and antioxidant activity of bovine serum albumin-coated catechin and epicatechin nanoparticles [224].

The absence of target specificity is another important challenge for dietary phytochemicals in cancer treatment. It has been shown that phytochemicals exert pleiotropic effects at the cellular level, whereas cancer cells activate other cell signals resulting from the failure of targeted therapy [225]. Scientists strive to utilize alternative strategies for managing these obstacles, including novel formulations for targeted delivery of phytochemicals, formulating semi-synthetic derivatives and analogs of phytochemicals, and development of novel drug delivery systems to enhance the effectiveness, protective characteristics, bioavailability, and pharmacokinetics of phytochemicals in humans $[28,226]$. Further studies are needed to meet the challenges of topical skin cancer formulations which include skin penetration, optimum drug concentration, stability, dosing strategy, and sustained drug release following topical application.

\section{Conclusions}

Dietary phytochemicals have several advantages for skin cancer prevention because they are readily available, cost-effective, and well tolerated. The use of dietary phytochemicals have an inverse relationship with skin cancer $[227,228]$. They are natural antioxidants, elevating the levels of antioxidant enzymes, CDKs, cyclins, p53, p21, and Bax. Moreover, they scavenge ROS, and decrease various molecular targets including EGFR, Notch-1, ERK, MAPK, NF-kB, STAT, $\beta$-catenin, PI3K, AKt, and mTOR [153,161,228]. Dietary phytochemicals can also inhibit the proliferation of established skin cancer cells by arresting the cell cycle, preventing metastasis and angiogenesis, suppressing EMT, regulating epigenetic alterations, and downregulating MMPs and COX-2 enzymes. Further investigation, including short-term human studies, may be beneficial in assessing the human relevance of the preclinical data. Moreover, skin cancer chemoprevention investigations involving whole fruits 
and vegetables are required in the humans who are at high risk, such as individuals with compromised immunity. Preclinical studies in models of high-risk skin carcinogenesis may show beneficial effects. Furthermore, whole fruits and vegetables may also be combined with existing therapeutic strategies for the better management of skin cancer.

Author Contributions: Y.S.L.: conceptualization, supervision; S.U.I., and H.A.: writing—original draft; M.B.A.: designed all the figures; M.I., A.S., and J.K.S.: writing—review and editing, visualization. All authors have read and agreed to the published version of the manuscript.

Funding: This research was funded by a National Research Foundation of Korea (NRF) grant from the Korean government (MSIT) (NRF- 2019R1A2C1003003).

Conflicts of Interest: The authors declare no conflict of interest.

\section{Abbreviations}

\begin{tabular}{|c|c|}
\hline $4 \mathrm{EBP}$ & Eukaryotic initiation factor $4 \mathrm{E}$ (eIF4E)-binding proteins \\
\hline $5 \mathrm{LOX}$ & 5-lipoxygenase \\
\hline 8-oxodG & 8-Oxo-2'-deoxyguanosine \\
\hline A375 & Human melanoma cell line \\
\hline A431 & Human epidermoid carcinoma cell line \\
\hline AIN-93G & Mice diet \\
\hline AK & Actinic keratosis \\
\hline Akt & Protein kinase B \\
\hline AP-1 & Activator protein 1 \\
\hline AQP3 & Aquaporin 3 \\
\hline Bax & Bcl-2-associated $X$ protein \\
\hline BCC & Basal cell carcinoma \\
\hline $\mathrm{Bcl} 2$ & B-cell lymphoma 2protein \\
\hline Bcl-3 & B-cell lymphoma 3-encoded protein \\
\hline CAPE & Caffeic acid phenethyl ester \\
\hline CD4 & Cluster of differentiation 4 \\
\hline CDK4 & Cyclin-dependent kinase 4 \\
\hline CDKN2 & Cyclin-dependent kinase inhibitor 2A \\
\hline CDKs & Cyclin-dependent kinases \\
\hline COX-1 & Cyclooxygenase 1 \\
\hline COX-2 & Cyclooxygenase 2 \\
\hline CPD & Carboxypeptidase D \\
\hline CRP & C-Reactive Protein \\
\hline CycD1 & Cyclin D1 \\
\hline DMBA & 7,12-Dimethylbenz[a]anthracene \\
\hline E2F1 & Transcription factor E2F1 \\
\hline E-cadherin & Epithelial cadherin \\
\hline EGCG & Epigallocatechin gallate \\
\hline EGFR & Epidermal growth factor receptor \\
\hline ERK & Extracellular signal-regulated kinase \\
\hline GIT & Gastrointestinal tract \\
\hline GP & Grape powder \\
\hline GPx & Glutathione peroxidase \\
\hline GST & Glutathione S-transferase \\
\hline HA14-1 & Ethyl-2-amino-6-bromo-4-(1-cyano-2-ethoxy-2-oxoethyl)-4H-chromene-3-carboxylate \\
\hline $\mathrm{HaCaT}$ & Aneuploid immortal keratinocyte cell line \\
\hline H-ras & Transforming protein p21 \\
\hline I3C & Indole-3-carbinol \\
\hline IL-1 $\beta$ & Interleukin-1 beta \\
\hline IL-6 & Interleukin-6 \\
\hline
\end{tabular}


ILGF-1 Insulin-like growth factor 1

iNOS Inducible nitric oxide synthase

IRS-1 Insulin receptor substrate 1

$\mathrm{J} / \mathrm{m}^{2} \quad$ Joule per square metre

JAK-2 Janus Kinase 2

JNK

c-Jun $\mathrm{N}$-terminal kinase

LRP

Lipoprotein receptor-related proteins

MAPK Mitogen-activated protein kinase

MDA 3,4-Methylene dioxy amphetamine

MDR-1 Multidrug resistance protein 1

MEK Mitogen-activated protein kinase kinase

miRNA microRNA

MITF Microphthalmia-associated transcription factor

MMP-9 Matrix metallopeptidase 9

MPO Myeloperoxidase

mPTP Mitochondrial permeability transition pore

mTOR The mammalian target of rapamycin

$N$-cadherin Neural cadherin

NER Nucleotide excision repair

NF- $\mathrm{B} \quad$ Nuclear factor kappa B

NHEK Normal human epidermal keratinocytes

NMSCs Nonmelanoma skin cancers

ODC Ornithine decarboxylase

$\mathrm{p} 21$

p38

p53

p65

PARP

Cyclin-dependent kinase inhibitor 1 or CDK-interacting protein 1

p38 mitogen-activated protein kinase

TP53 or tumor protein

nuclear factor NF-kappa-B p65 subunit

PFE

Poly (ADP-ribose) polymerase

Proliferating cell nuclear antigen

$\mathrm{PGE}_{2} \quad$ Prostaglandin $\mathrm{E}_{2}$

PI3-K Phosphoinositide 3-kinase

PKB

ROS

RV Resvertrol

Protein kinase B, also known as Akt

SCC Squamous cell carcinoma

SOD Superoxide dismutase

STAT3 Signal transducer and activator of transcription 3

TGF- $\beta$ Transforming growth factor beta 1

TPA 12-O-tetradecanoylphorbol-13-acetate

TRAF6 Tumor necrosis factor receptor (TNFR)-associated factor 6

TRK Tyrosine kinases

UA Ursolic acid

UV Ultraviolet

UVA Ultraviolet A

UVB Ultraviolet B

VEGF Vascular endothelial growth factor

WNT Wingless-related integration site 


\section{References}

1. Brohem, C.A.; da Silva Cardeal, L.B.; Tiago, M.; Soengas, M.S.; de Moraes Barros, S.B.; Maria-Engler, S.S. Artificial skin in perspective: Concepts and applications. Pigment. Cell Melanoma Res. 2011, 24, 35-50. [CrossRef]

2. Kumari, S.; Pasparakis, M. Epithelial cell death and inflammation in skin. In Apoptotic and Non-Apoptotic Cell Death; Springer: Cham, Switzerland, 2015; pp. 77-93.

3. Fuchs, E.; Raghavan, S. Getting under the skin of epidermal morphogenesis. Nat. Rev. Genet. 2002, 3, 199-209. [CrossRef]

4. Apalla, Z.; Nashan, D.; Weller, R.B.; Castellsagué, X. Skin cancer: Epidemiology, disease burden, pathophysiology, diagnosis, and therapeutic approaches. Dermatol. Ther. 2017, 7, 5-19. [CrossRef]

5. Bickers, D.R.; Athar, M. Oxidative stress in the pathogenesis of skin disease. J. Investig. Dermatol. 2006, 126, 2565-2575. [CrossRef]

6. Pitot, H.C.; Dragan, Y.P. Facts and theories concerning the mechanisms of carcinogenesis. FASEB J. 1991, 5 , 2280-2286. [CrossRef]

7. Benjamin, C.L.; Ananthaswamy, H.N. p53 and the pathogenesis of skin cancer. Toxicol. Appl. Pharmacol. 2007, 224, 241-248. [CrossRef]

8. Agar, N.S.; Halliday, G.M.; Barnetson, R.S.; Ananthaswamy, H.N.; Wheeler, M.; Jones, A.M. The basal layer in human squamous tumors harbors more UVA than UVB fingerprint mutations: A role for UVA in human skin carcinogenesis. Proc. Natl. Acad. Sci. USA 2004, 101, 4954-4959. [CrossRef] [PubMed]

9. Rebel, H.; Mosnier, L.O.; Berg, R.J.; Westerman-de Vries, A.; van Steeg, H.; van Kranen, H.J.; de Gruijl, F.R. Early p53-positive foci as indicators of tumor risk in ultraviolet-exposed hairless mice: Kinetics of induction, effects of DNA repair deficiency, and p53 heterozygosity. Cancer Res. 2001, 61, 977-983. [PubMed]

10. Ra, S.H.; Li, X.; Binder, S. Molecular discrimination of cutaneous squamous cell carcinoma from actinic keratosis and normal skin. Mod. Pathol. 2011, 24, 963-973. [CrossRef] [PubMed]

11. Rogers, H.W.; Weinstock, M.A.; Feldman, S.R.; Coldiron, B.M. Incidence estimate of nonmelanoma skin cancer (keratinocyte carcinomas) in the US population, 2012. JAMA Dermatol. 2015, 151, 1081-1086. [CrossRef]

12. Christenson, L.J.; Borrowman, T.A.; Vachon, C.M.; Tollefson, M.M.; Otley, C.C.; Weaver, A.L.; Roenigk, R.K. Incidence of basal cell and squamous cell carcinomas in a population younger than 40 years. JAMA 2005, 294, 681-690. [CrossRef] [PubMed]

13. Wu, S.; Han, J.; Li, W.-Q.; Li, T.; Qureshi, A.A. Basal-cell carcinoma incidence and associated risk factors in US women and men. Am. J. Epidemiol. 2013, 178, 890-897. [CrossRef]

14. Guy, G.P., Jr.; Machlin, S.R.; Ekwueme, D.U.; Yabroff, K.R. Prevalence and costs of skin cancer treatment in the US, 2002-2006 and 2007-2011. Am. J. Prev. Med. 2015, 48, 183-187. [CrossRef] [PubMed]

15. Rees, J.R.; Zens, M.S.; Celaya, M.O.; Riddle, B.L.; Karagas, M.R.; Peacock, J.L. Survival after squamous cell and basal cell carcinoma of the skin: A retrospective cohort analysis. Int. J. Cancer 2015, 137, 878-884. [CrossRef] [PubMed]

16. Jensen, A.Ø.; Lamberg, A.L.; Jacobsen, J.B.; Olesen, A.B.; Sørensen, H.T. Non-melanoma skin cancer and ten-year all-cause mortality: A population-based cohort study. Acta Derm. Venereol. 2010, 90, 362-367. [CrossRef]

17. Epstein, E.H. Basal cell carcinomas: Attack of the hedgehog. Nat. Rev. Cancer 2008, 8, 743-754. [CrossRef]

18. Alam, M.; Armstrong, A.; Baum, C.; Bordeaux, J.S.; Brown, M.; Busam, K.J.; Eisen, D.B.; Iyengar, V.; Lober, C.; Margolis, D.J. Guidelines of care for the management of cutaneous squamous cell carcinoma. J. Am. Acad. Dermatol. 2018, 78, 560-578.

19. Brantsch, K.D.; Meisner, C.; Schönfisch, B.; Trilling, B.; Wehner-Caroli, J.; Röcken, M.; Breuninger, H. Analysis of risk factors determining prognosis of cutaneous squamous-cell carcinoma: A prospective study. Lancet Oncol. 2008, 9, 713-720. [CrossRef]

20. Cooper, J.Z.; Brown, M.D. Special concern about squamous cell carcinoma of the scalp in organ transplant recipients. Arch. Dermatol. 2006, 142, 755-758. [CrossRef]

21. Madan, V.; Lear, J.T.; Szeimies, R.-M. Non-melanoma skin cancer. Lancet 2010, 375, 673-685. [CrossRef]

22. Werlinger, K.D.; Upton, G.; Moore, A.Y. Recurrence rates of primary nonmelanoma skin cancers treated by surgical excision compared to electrodesiccation-curettage in a private dermatological practice. Dermatol. Surg. 2002, 28, 1138-1142. 
23. Krzyzanowska, J.; Czubacka, A.; Oleszek, W. Dietary phytochemicals and human health. In Bio-Farms for Nutraceuticals; Springer: Boston, MA, USA, 2010; pp. 74-98.

24. Probst, Y.C.; Guan, V.X.; Kent, K. Dietary phytochemical intake from foods and health outcomes: A systematic review protocol and preliminary scoping. BMJ Open 2017, 7. [CrossRef] [PubMed]

25. Bansal, M.; Singh, N.; Pal, S.; Dev, I.; Ansari, K.M. Chemopreventive role of dietary phytochemicals in colorectal cancer. In Advances in Molecular Toxicology; Fishbein, J.C., Heilman, J.M., Eds.; Elsevier: Amsterdam, The Netherlands, 2018; Volume 12, pp. 69-121.

26. Forni, C.; Facchiano, F.; Bartoli, M.; Pieretti, S.; Facchiano, A.; D’Arcangelo, D.; Norelli, S.; Valle, G.; Nisini, R.; Beninati, S. Beneficial role of phytochemicals on oxidative stress and age-related diseases. BioMed Res. Int. 2019, 2019. [CrossRef] [PubMed]

27. Aggarwal, B.B.; Bhardwaj, A.; Aggarwal, R.S.; Seeram, N.P.; Shishodia, S.; Takada, Y. Role of resveratrol in prevention and therapy of cancer: Preclinical and clinical studies. Anticancer. Res. 2004, 24, 2783-2840. [PubMed]

28. Islam, S.U.; Ahmed, M.B.; Ul-Islam, M.; Shehzad, A.; Lee, Y.S. Switching from Conventional to Nano-natural Phytochemicals to Prevent and Treat Cancers: Special Emphasis on Resveratrol. Curr. Pharm. Des. 2019, 25, 3620-3632. [CrossRef]

29. Dong, Z. Molecular mechanism of the chemopreventive effect of resveratrol. Mutat. Res. Fundam. Mol. Mech. Mutagenesis 2003, 523, 145-150. [CrossRef]

30. Brisdelli, F.; D'Andrea, G.; Bozzi, A. Resveratrol: A natural polyphenol with multiple chemopreventive properties. Curr. Drug Metab. 2009, 10, 530-546. [CrossRef]

31. Aziz, M.H.; Reagan-Shaw, S.; Wu, J.; Longley, B.J.; Ahmad, N. Chemoprevention of skin cancer by grape constituent resveratrol: Relevance to human disease? FASEB J. 2005, 19, 1193-1195. [CrossRef]

32. Ndiaye, M.; Philippe, C.; Mukhtar, H.; Ahmad, N. The grape antioxidant resveratrol for skin disorders: Promise, prospects, and challenges. Arch. Biochem. Biophys. 2011, 508, 164-170. [CrossRef]

33. Kowalczyk, M.C.; Walaszek, Z.; Kowalczyk, P.; Kinjo, T.; Hanausek, M.; Slaga, T.J. Differential effects of several phytochemicals and their derivatives on murine keratinocytes in vitro and in vivo: Implications for skin cancer prevention. Carcinogenesis 2009, 30, 1008-1015. [CrossRef]

34. Jagdeo, J.; Adams, L.; Lev-Tov, H.; Sieminska, J.; Michl, J.; Brody, N. Dose-dependent antioxidant function of resveratrol demonstrated via modulation of reactive oxygen species in normal human skin fibroblasts in vitro. J. Drugs Dermatol. 2010, 9, 1523-1526. [PubMed]

35. Kundu, J.K.; Shin, Y.K.; Kim, S.H.; Surh, Y.-J. Resveratrol inhibits phorbol ester-induced expression of COX-2 and activation of NF- $\mathrm{KB}$ in mouse skin by blocking IKB kinase activity. Carcinogenesis 2006, 27, 1465-1474. [CrossRef] [PubMed]

36. Niles, R.M.; Cook, C.P.; Meadows, G.G.; Fu, Y.-M.; McLaughlin, J.L.; Rankin, G.O. Resveratrol is rapidly metabolized in athymic (nu/nu) mice and does not inhibit human melanoma xenograft tumor growth. J. Nutr. 2006, 136, 2542-2546. [CrossRef] [PubMed]

37. Reagan-Shaw, S.; Afaq, F.; Aziz, M.H.; Ahmad, N. Modulations of critical cell cycle regulatory events during chemoprevention of ultraviolet B-mediated responses by resveratrol in SKH-1 hairless mouse skin. Oncogene 2004, 23, 5151-5160. [CrossRef]

38. Wu, Z.; Uchi, H.; Morino-Koga, S.; Shi, W.; Furue, M. Resveratrol inhibition of human keratinocyte proliferation via SIRT1/ARNT/ERK dependent downregulation of aquaporin 3. J. Dermatol. Sci. 2014, 75, 16-23. [CrossRef]

39. Osmond, G.W.; Augustine, C.K.; Zipfel, P.A.; Padussis, J.; Tyler, D.S. Enhancing melanoma treatment with resveratrol. J. Surg. Res. 2012, 172, 109-115. [CrossRef]

40. Bhattacharya, S.; Darjatmoko, S.R.; Polans, A.S. Resveratrol modulates the malignant properties of cutaneous melanoma via changes in the activation and attenuation of the anti-apoptotic proto-oncogenic protein Akt/PKB. Melanoma Res. 2011, 21, 180. [CrossRef]

41. Farris, P.; Yatskayer, M.; Chen, N.; Krol, Y.; Oresajo, C. Evaluation of efficacy and tolerance of a nighttime topical antioxidant containing resveratrol, baicalin, and vitamin e for treatment of mild to moderately photodamaged skin. J. Drugs Dermatol. JDD 2014, 13, 1467.

42. Boo, Y.C. Human Skin Lightening Efficacy of Resveratrol and Its Analogs: From in Vitro Studies to Cosmetic Applications. Antioxidants 2019, 8, 332. [CrossRef] 
43. Islam, S.U.; Shehzad, A.; Sonn, J.K.; Lee, Y.S. PRPF overexpression induces drug resistance through actin cytoskeleton rearrangement and epithelial-mesenchymal transition. Oncotarget 2017, 8, 56659. [CrossRef]

44. Gupta, S.C.; Patchva, S.; Koh, W.; Aggarwal, B.B. Discovery of curcumin, a component of golden spice, and its miraculous biological activities. Clin. Exp. Pharmacol. Physiol. 2012, 39, 283-299. [CrossRef] [PubMed]

45. Dahmke, I.N.; Backes, C.; Rudzitis-Auth, J.; Laschke, M.W.; Leidinger, P.; Menger, M.D.; Meese, E.; Mahlknecht, U. Curcumin intake affects miRNA signature in murine melanoma with mmu-miR-205-5p most significantly altered. PLoS ONE 2013, 8, e81122. [CrossRef] [PubMed]

46. Gupta, S.C.; Patchva, S.; Aggarwal, B.B. Therapeutic roles of curcumin: Lessons learned from clinical trials. AAPS J. 2013, 15, 195-218. [CrossRef] [PubMed]

47. Santana-Martínez, R.A.; Silva-Islas, C.A.; Fernández-Orihuela, Y.Y.; Barrera-Oviedo, D.; Pedraza-Chaverri, J.; Hernández-Pando, R.; Maldonado, P.D. The therapeutic effect of curcumin in quinolinic acid-induced neurotoxicity in rats is associated with BDNF, ERK1/2, Nrf2, and antioxidant enzymes. Antioxidants 2019, 8, 388. [CrossRef] [PubMed]

48. Paunkov, A.; Chartoumpekis, D.V.; Ziros, P.G.; Sykiotis, G.P. A bibliometric review of the Keap1/Nrf2 pathway and its related antioxidant compounds. Antioxidants 2019, 8, 353. [CrossRef]

49. Harmand, P.-O.; Duval, R.; Liagre, B.; Jayat-Vignoles, C.; Beneytout, J.-L.; Delage, C.; Simon, A. Ursolic acid induces apoptosis through caspase-3 activation and cell cycle arrest in HaCat cells. Int. J. Oncol. 2003, 23, 105-112. [CrossRef]

50. Shishodia, S.; Majumdar, S.; Banerjee, S.; Aggarwal, B.B. Ursolic acid inhibits nuclear factor- $k B$ activation induced by carcinogenic agents through suppression of IKB $\alpha$ kinase and p65 phosphorylation: Correlation with down-regulation of cyclooxygenase 2, matrix metalloproteinase 9, and cyclin D1. Cancer Res. 2003, 63, 4375-4383.

51. Harmand, P.O.; Duval, R.; Delage, C.; Simon, A. Ursolic acid induces apoptosis through mitochondrial intrinsic pathway and caspase-3 activation in M4Beu melanoma cells. Int. J. Cancer 2005, 114, 1-11. [CrossRef]

52. Manu, K.; Kuttan, G. Ursolic acid induces apoptosis by activating p53 and caspase-3 gene expressions and suppressing NF- $\mathrm{kB}$ mediated activation of bcl-2 in B16F-10 melanoma cells. Int. Immunopharmacol. 2008, 8, 974-981. [CrossRef]

53. Prasad, N.R.; Ramachandran, S.; Pugalendi, K.; Menon, V.P. Modulation of UVB-induced Oxidative Stress by Ursolic Acid in Human Blood Lymphocytes. Asian J. Biochem. 2008, 3, 11-18. [CrossRef]

54. Both, D.M.; Goodtzova, K.; Yarosh, D.B.; Brown, D.A. Liposome-encapsulated ursolic acid increases ceramides and collagen in human skin cells. Arch. Dermatol. Res. 2002, 293, 569-575. [CrossRef] [PubMed]

55. Singh, M.; Suman, S.; Shukla, Y. New enlightenment of skin cancer chemoprevention through phytochemicals: In vitro and in vivo studies and the underlying mechanisms. BioMed Res. Int. 2014, 2014. [CrossRef] [PubMed]

56. Wei, H.; Saladi, R.; Lu, Y.; Wang, Y.; Palep, S.R.; Moore, J.; Phelps, R.; Shyong, E.; Lebwohl, M.G. Isoflavone genistein: Photoprotection and clinical implications in dermatology. J. Nutr. 2003, 133, 3811S-3819S. [CrossRef]

57. Rusin, A.; Krawczyk, Z.; Grynkiewicz, G.; Gogler, A.; Zawisza-Puchałka, J.; Szeja, W. Synthetic derivatives of genistein, their properties and possible applications. Acta Biochim. Pol. 2010, 57. [CrossRef]

58. Sarkar, F.H.; Li, Y. Mechanisms of cancer chemoprevention by soy isoflavone genistein. Cancer Metastasis Rev. 2002, 21, 265-280. [CrossRef]

59. Li, Q.-S.; Li, C.-Y.; Li, Z.-L.; Zhu, H.-L. Genistein and its synthetic analogs as anticancer agents. Anti-Cancer Agents Med. Chem. 2012, 12, 271-281. [CrossRef]

60. Rusin, A.; Zawisza-Puchałka, J.; Kujawa, K.; Gogler-Pigłowska, A.; Wietrzyk, J.; Świtalska, M.; Głowala-Kosińska, M.; Gruca, A.; Szeja, W.; Krawczyk, Z. Synthetic conjugates of genistein affecting proliferation and mitosis of cancer cells. Bioorganic Med. Chem. 2011, 19, 295-305. [CrossRef]

61. Chandra Pal, H.; Marchiony Hunt, K.; Diamond, A.; Elmets, C.A.; Afaq, F. Phytochemicals for the management of melanoma. Mini Rev. Med. Chem. 2016, 16, 953-979. [CrossRef]

62. Wei, H.; Zhang, X.; Wang, Y.; Lebwohl, M. Inhibition of ultraviolet light-induced oxidative events in the skin and internal organs of hairless mice by isoflavone genistein. Cancer Lett. 2002, 185, 21-29. [CrossRef]

63. Danciu, C.; Borcan, F.; Bojin, F.; Zupko, I.; Dehelean, C. Effect of the isoflavone genistein on tumor size, metastasis potential and melanization in a B16 mouse model of murine melanoma. Nat. Prod. Commun. 2013, 8. [CrossRef] 
64. Casagrande, F.; Darbon, J.-M. p21CIP1 is dispensable for the G2 arrest caused by genistein in human melanoma cells. Exp. Cell Res. 2000, 258, 101-108. [CrossRef] [PubMed]

65. Darbon, J.-M.; Penary, M.; Escalas, N.; Casagrande, F.; Goubin-Gramatica, F.; Baudouin, C.; Ducommun, B. Distinct Chk2 activation pathways are triggered by genistein and DNA-damaging agents in human melanoma cells. J. Biol. Chem. 2000, 275, 15363-15369. [CrossRef] [PubMed]

66. Park, C.; Cha, H.-J.; Lee, H.; Hwang-Bo, H.; Ji, S.Y.; Kim, M.Y.; Hong, S.H.; Jeong, J.-W.; Han, M.H.; Choi, S.H. Induction of G2/M cell cycle arrest and apoptosis by genistein in human bladder cancer T24 cells through inhibition of the ROS-dependent PI3k/Akt signal transduction pathway. Antioxidants 2019, 8, 327. [CrossRef] [PubMed]

67. Aggarwal, B.B.; Ichikawa, H. Molecular targets and anticancer potential of indole-3-carbinol and its derivatives. Cell Cycle 2005, 4, 1201-1215. [CrossRef] [PubMed]

68. Safe, S.; Papineni, S.; Chintharlapalli, S. Cancer chemotherapy with indole-3-carbinol, bis (3'-indolyl) methane and synthetic analogs. Cancer Lett. 2008, 269, 326-338. [CrossRef] [PubMed]

69. Weng, J.-R.; Tsai, C.-H.; Kulp, S.K.; Wang, D.; Lin, C.-H.; Yang, H.-C.; Ma, Y.; Sargeant, A.; Chiu, C.-F.; Tsai, M.-H. A potent indole-3-carbinol-derived antitumor agent with pleiotropic effects on multiple signaling pathways in prostate cancer cells. Cancer Res. 2007, 67, 7815-7824. [CrossRef] [PubMed]

70. Kim, D.-S.; Jeong, Y.-M.; Moon, S.-I.; Kim, S.-Y.; Kwon, S.-B.; Park, E.-S.; Youn, S.-W.; Park, K.-C. Indole-3-carbinol enhances ultraviolet B-induced apoptosis by sensitizing human melanoma cells. Cell. Mol. Life Sci. CMLS 2006, 63, 2661-2668. [CrossRef]

71. Kim, S.-Y.; Kim, D.-S.; Jeong, Y.-M.; Moon, S.-I.; Kwon, S.-B.; Park, K.-C. Indole-3-carbinol and ultraviolet B induce apoptosis of human melanoma cells via down-regulation of MITF. Pharm. Int. J. Pharm. Sci. 2011, 66, 982-987.

72. Aronchik, I.; Kundu, A.; Quirit, J.G.; Firestone, G.L. The antiproliferative response of indole-3-carbinol in human melanoma cells is triggered by an interaction with NEDD4-1 and disruption of wild-type PTEN degradation. Mol. Cancer Res. 2014, 12, 1621-1634. [CrossRef]

73. Bode, A.M.; Dong, Z. The two faces of capsaicin. Cancer Res. 2011, 71, 2809-2814. [CrossRef]

74. Hwang, M.K.; Bode, A.M.; Byun, S.; Song, N.R.; Lee, H.J.; Lee, K.W.; Dong, Z. Cocarcinogenic effect of capsaicin involves activation of EGFR signaling but not TRPV1. Cancer Res. 2010, 70, 6859-6869. [CrossRef] [PubMed]

75. Hail, N., Jr.; Lotan, R. Examining the role of mitochondrial respiration in vanilloid-induced apoptosis. J. Natl. Cancer Inst. 2002, 94, 1281-1292. [CrossRef] [PubMed]

76. Shin, D.-H.; Kim, O.-H.; Jun, H.-S.; Kang, M.-K. Inhibitory effect of capsaicin on B16-F10 melanoma cell migration via the phosphatidylinositol 3-kinase/Akt/Rac1 signal pathway. Exp. Mol. Med. 2008, 40, 486-494. [CrossRef] [PubMed]

77. Marques, C.M.; Dibden, C.; Danson, S.; Haycock, J.W.; MacNeil, S. Combined effects of capsaicin and HA14-1 in inducing apoptosis in melanoma cells. J. Cosmet. Dermatol. Sci. Appl. 2013, 3, 175. [CrossRef]

78. Mason, L.; Moore, R.A.; Derry, S.; Edwards, J.E.; McQuay, H.J. Systematic review of topical capsaicin for the treatment of chronic pain. BMJ 2004, 328, 991. [CrossRef]

79. Hamed, M.; Kalita, D.; Bartolo, M.E.; Jayanty, S.S. Capsaicinoids, polyphenols and antioxidant activities of capsicum annuum: Comparative study of the effect of ripening stage and cooking methods. Antioxidants 2019, 8, 364. [CrossRef]

80. Wang, Y.; Zhang, D.; Liu, Z.; Liu, G.; Duan, C.; Jia, L.; Feng, F.; Zhang, X.; Shi, Y.; Zhang, Q. In vitro and in vivo evaluation of silybin nanosuspensions for oral and intravenous delivery. Nanotechnology 2010, 21, 155104. [CrossRef]

81. Deep, G.; Agarwal, R. Antimetastatic efficacy of silibinin: Molecular mechanisms and therapeutic potential against cancer. Cancer Metastasis Rev. 2010, 29, 447-463. [CrossRef]

82. Deep, G.; Singh, R.; Agarwal, C.; Kroll, D.; Agarwal, R. Silymarin and silibinin cause G1 and G2-M cell cycle arrest via distinct circuitries in human prostate cancer PC3 cells: A comparison of flavanone silibinin with flavanolignan mixture silymarin. Oncogene 2006, 25, 1053-1069. [CrossRef]

83. Singh, R.P.; Dhanalakshmi, S.; Agarwal, C.; Agarwal, R. Silibinin strongly inhibits growth and survival of human endothelial cells via cell cycle arrest and downregulation of survivin, Akt and NF-k B: Implications for angioprevention and antiangiogenic therapy. Oncogene 2005, 24, 1188-1202. [CrossRef] 
84. Singh, R.P.; Deep, G.; Chittezhath, M.; Kaur, M.; Dwyer-Nield, L.D.; Malkinson, A.M.; Agarwal, R. Effect of silibinin on the growth and progression of primary lung tumors in mice. J. Natl. Cancer Inst. 2006, 98, 846-855. [CrossRef] [PubMed]

85. Kaur, M.; Velmurugan, B.; Tyagi, A.; Deep, G.; Katiyar, S.; Agarwal, C.; Agarwal, R. Silibinin suppresses growth and induces apoptotic death of human colorectal carcinoma LoVo cells in culture and tumor xenograft. Mol. Cancer Ther. 2009, 8, 2366-2374. [CrossRef] [PubMed]

86. Son, Y.-g.; Kim, E.H.; Kim, J.Y.; Kim, S.U.; Kwon, T.K.; Yoon, A.-R.; Yun, C.-O.; Choi, K.S. Silibinin sensitizes human glioma cells to TRAIL-mediated apoptosis via DR5 up-regulation and down-regulation of c-FLIP and survivin. Cancer Res. 2007, 67, 8274-8284. [CrossRef]

87. Vaid, M.; Katiyar, S.K. Molecular mechanisms of inhibition of photocarcinogenesis by silymarin, a phytochemical from milk thistle (Silybum marianum L. Gaertn.). Int. J. Oncol. 2010, 36, 1053-1060.

88. Dhanalakshmi, S.; Mallikarjuna, G.; Singh, R.P.; Agarwal, R. Dual efficacy of silibinin in protecting or enhancing ultraviolet B radiation-caused apoptosis in HaCaT human immortalized keratinocytes. Carcinogenesis 2004, 25, 99-106. [CrossRef]

89. Singh, R.P.; Dhanalakshmi, S.; Mohan, S.; Agarwal, C.; Agarwal, R. Silibinin inhibits UVB-and epidermal growth factor-induced mitogenic and cell survival signaling involving activator protein-1 and nuclear factor-kB in mouse epidermal JB6 cells. Mol. Cancer Ther. 2006, 5, 1145-1153. [CrossRef] [PubMed]

90. Mallikarjuna, G.; Dhanalakshmi, S.; Singh, R.P.; Agarwal, C.; Agarwal, R. Silibinin protects against photocarcinogenesis via modulation of cell cycle regulators, mitogen-activated protein kinases, and Akt signaling. Cancer Res. 2004, 64, 6349-6356. [CrossRef]

91. Singh, R.P.; Raina, K.; Deep, G.; Chan, D.; Agarwal, R. Silibinin suppresses growth of human prostate carcinoma PC-3 orthotopic xenograft via activation of extracellular signal-regulated kinase 1/2 and inhibition of signal transducers and activators of transcription signaling. Clin. Cancer Res. 2009, 15, 613-621. [CrossRef]

92. Chen, P.-N.; Hsieh, Y.-S.; Chiou, H.-L.; Chu, S.-C. Silibinin inhibits cell invasion through inactivation of both PI3K-Akt and MAPK signaling pathways. Chem. Biol. Interact. 2005, 156, 141-150. [CrossRef]

93. Vaid, M.; Prasad, R.; Sun, Q.; Katiyar, S.K. Silymarin targets $\beta$-catenin signaling in blocking migration/invasion of human melanoma cells. PLoS ONE 2011, 6, e23000. [CrossRef]

94. Linden, K.G.; Carpenter, P.M.; McLaren, C.E.; Barr, R.J.; Rite, P.; Sun, J.D.; Li, K.-T.; Viner, J.L.; Meyskens, F.L. Chemoprevention of nonmelanoma skin cancer: Experience with a polyphenol from green tea. In Tumor Prevention and Genetics; Springer: Berlin/Heidelberg, Germany, 2003; pp. 165-171.

95. Farrar, M.D.; Nicolaou, A.; Clarke, K.A.; Mason, S.; Massey, K.A.; Dew, T.P.; Watson, R.E.; Williamson, G.; Rhodes, L.E. A randomized controlled trial of green tea catechins in protection against ultraviolet radiation-induced cutaneous inflammation, 2. Am. J. Clin. Nutr. 2015, 102, 608-615. [CrossRef] [PubMed]

96. Zhang, J.; Lei, Z.; Huang, Z.; Zhang, X.; Zhou, Y.; Luo, Z.; Zeng, W.; Su, J.; Peng, C.; Chen, X. Epigallocatechin-3-gallate (EGCG) suppresses melanoma cell growth and metastasis by targeting TRAF6 activity. Oncotarget 2016, 7, 79557. [CrossRef] [PubMed]

97. Ellis, L.Z.; Liu, W.; Luo, Y.; Okamoto, M.; Qu, D.; Dunn, J.H.; Fujita, M. Green tea polyphenol epigallocatechin-3-gallate suppresses melanoma growth by inhibiting inflammasome and IL-1 $\beta$ secretion. Biochem. Biophys. Res. Commun. 2011, 414, 551-556. [CrossRef] [PubMed]

98. Nihal, M.; Ahsan, H.; Siddiqui, I.A.; Mukhtar, H.; Ahmad, N.; Wood, G.S. (-)-Epigallocatechin-3-gallate (EGCG) sensitizes melanoma cells to interferon induced growth inhibition in a mouse model of human melanoma. Cell Cycle 2009, 8, 2057-2063. [CrossRef] [PubMed]

99. Mantena, S.K.; Meeran, S.M.; Elmets, C.A.; Katiyar, S.K. Orally administered green tea polyphenols prevent ultraviolet radiation-induced skin cancer in mice through activation of cytotoxic $\mathrm{T}$ cells and inhibition of angiogenesis in tumors. J. Nutr. 2005, 135, 2871-2877. [CrossRef]

100. Afaq, F.; Adhami, V.M.; Ahmad, N.; Mukhtar, H. Inhibition of ultraviolet B-mediated activation of nuclear factor $\mathrm{K}$ B in normal human epidermal keratinocytes by green tea Constituent (-)-epigallocatechin-3-gallate. Oncogene 2003, 22, 1035-1044. [CrossRef]

101. Katiyar, S.K.; Afaq, F.; Perez, A.; Mukhtar, H. Green tea polyphenol (-)-epigallocatechin-3-gallate treatment of human skin inhibits ultraviolet radiation-induced oxidative stress. Carcinogenesis 2001, 22, 287-294. [CrossRef]

102. Kaur, G.; Athar, M.; Alam, M.S. Eugenol precludes cutaneous chemical carcinogenesis in mouse by preventing oxidative stress and inflammation and by inducing apoptosis. Mol. Carcinog. 2010, 49, 290-301. [CrossRef] 
103. Ghosh, R.; Nadiminty, N.; Fitzpatrick, J.E.; Alworth, W.L.; Slaga, T.J.; Kumar, A.P. Eugenol causes melanoma growth suppression through inhibition of E2F1 transcriptional activity. J. Biol. Chem. 2005, 280, 5812-5819. [CrossRef]

104. Pal, D.; Banerjee, S.; Mukherjee, S.; Roy, A.; Panda, C.K.; Das, S. Eugenol restricts DMBA croton oil induced skin carcinogenesis in mice: Downregulation of c-Myc and H-ras, and activation of p53 dependent apoptotic pathway. J. Dermatol. Sci. 2010, 59, 31-39. [CrossRef]

105. Esmaeili, F.; Rajabnejhad, S.; Partoazar, A.R.; Mehr, S.E.; Faridi-Majidi, R.; Sahebgharani, M.; Syedmoradi, L.; Rajabnejhad, M.R.; Amani, A. Anti-inflammatory effects of eugenol nanoemulsion as a topical delivery system. Pharm. Dev. Technol. 2016, 21, 887-893. [CrossRef] [PubMed]

106. Wu, J.; Omene, C.; Karkoszka, J.; Bosland, M.; Eckard, J.; Klein, C.B.; Frenkel, K. Caffeic acid phenethyl ester (CAPE), derived from a honeybee product propolis, exhibits a diversity of anti-tumor effects in pre-clinical models of human breast cancer. Cancer Lett. 2011, 308, 43-53. [CrossRef] [PubMed]

107. Lee, K.W.; Kang, N.J.; Kim, J.H.; Lee, K.M.; Lee, D.E.; Hur, H.J.; Lee, H.J. Caffeic acid phenethyl ester inhibits invasion and expression of matrix metalloproteinase in SK-Hep1 human hepatocellular carcinoma cells by targeting nuclear factor kappa B. Genes Nutr. 2008, 2, 319-322. [CrossRef] [PubMed]

108. Onori, P.; DeMorrow, S.; Gaudio, E.; Franchitto, A.; Mancinelli, R.; Venter, J.; Kopriva, S.; Ueno, Y.; Alvaro, D.; Savage, J. Caffeic acid phenethyl ester decreases cholangiocarcinoma growth by inhibition of NF- $\mathrm{BB}$ and induction of apoptosis. Int. J. Cancer 2009, 125, 565-576. [CrossRef] [PubMed]

109. Wu, C.-S.; Chen, M.-F.; Lee, I.-L.; Tung, S.-Y. Predictive role of nuclear factor- $k B$ activity in gastric cancer: A promising adjuvant approach with caffeic acid phenethyl ester. J. Clin. Gastroenterol. 2007, 41, 894-900. [CrossRef] [PubMed]

110. Nakashima, S.; Matsuda, H.; Oda, Y.; Nakamura, S.; Xu, F.; Yoshikawa, M. Melanogenesis inhibitors from the desert plant Anastatica hierochuntica in B16 melanoma cells. Bioorg. Med. Chem. 2010, 18, 2337-2345. [CrossRef] [PubMed]

111. Iwashita, K.; Kobori, M.; Yamaki, K.; Tsushida, T. Flavonoids inhibit cell growth and induce apoptosis in B16 melanoma 4A5 cells. Biosci. Biotechnol. Biochem. 2000, 64, 1813-1820. [CrossRef]

112. Horváthová, K.; Chalupa, I.; Sebová, L.; Tóthová, D.; Vachálková, A. Protective effect of quercetin and luteolin in human melanoma HMB-2 cells. Mutat. Res. 2005, 565, 105-112. [CrossRef]

113. Horibe, I.; Satoh, Y.; Shiota, Y.; Kumagai, A.; Horike, N.; Takemori, H.; Uesato, S.; Sugie, S.; Obata, K.; Kawahara, H.; et al. Induction of melanogenesis by 4'-O-methylated flavonoids in B16F10 melanoma cells. J. Nat. Med. 2013, 67, 705-710. [CrossRef]

114. López-Lázaro, M. Distribution and biological activities of the flavonoid luteolin. Mini Rev. Med. Chem. 2009, 9, 31-59. [CrossRef]

115. Kim, S.O.; Chun, K.S.; Kundu, J.K.; Surh, Y.J. Inhibitory effects of [6]-gingerol on PMA-induced COX-2 expression and activation of NF-KB and p38 MAPK in mouse skin. Biofactors 2004, 21, 27-31. [CrossRef] [PubMed]

116. Kim, J.-K.; Kim, Y.; Na, K.-M.; Surh, Y.-J.; Kim, T.-Y. [6]-Gingerol prevents UVB-induced ROS production and COX-2 expression in vitro and in vivo. Free Radic. Res. 2007, 41, 603-614. [CrossRef] [PubMed]

117. Bode, A.M.; Ma, W.-Y.; Surh, Y.-J.; Dong, Z. Inhibition of epidermal growth factor-induced cell transformation and activator protein 1 activation by [6]-gingerol. Cancer Res. 2001, 61, 850-853. [PubMed]

118. Nigam, N.; George, J.; Srivastava, S.; Roy, P.; Bhui, K.; Singh, M.; Shukla, Y. Induction of apoptosis by [6]-gingerol associated with the modulation of p53 and involvement of mitochondrial signaling pathway in B [a] P-induced mouse skin tumorigenesis. Cancer Chemother. Pharmacol. 2010, 65, 687-696. [CrossRef]

119. Ratcharin, N.; Wongtrakul, P.; Indranupakorn, R. Preparation of Zingiber officinale extract loaded solid lipid nanoparticles. In Proceedings of Advanced Materials Research; Trans. Tech. Publications Ltd.: Bäch, Switzerland, 2012; pp. 389-392.

120. Moon, M.K.; Lee, Y.J.; Kim, J.S.; Kang, D.G.; Lee, H.S. Effect of caffeic acid on tumor necrosis factor-alpha-induced vascular inflammation in human umbilical vein endothelial cells. Biol. Pharm. Bull. 2009, 32, 1371-1377. [CrossRef]

121. Tsai, S.-j.; Chao, C.-y.; Yin, M.-c. Preventive and therapeutic effects of caffeic acid against inflammatory injury in striatum of MPTP-treated mice. Eur. J. Pharmacol. 2011, 670, 441-447. [CrossRef] 
122. Kang, N.J.; Lee, K.W.; Kim, B.H.; Bode, A.M.; Lee, H.-J.; Heo, Y.-S.; Boardman, L.; Limburg, P.; Lee, H.J.; Dong, Z. Coffee phenolic phytochemicals suppress colon cancer metastasis by targeting MEK and TOPK. Carcinogenesis 2011, 32, 921-928. [CrossRef]

123. Jung, J.E.; Kim, H.S.; Lee, C.S.; Park, D.-H.; Kim, Y.-N.; Lee, M.-J.; Lee, J.W.; Park, J.-W.; Kim, M.-S.; Ye, S.K. Caffeic acid and its synthetic derivative CADPE suppress tumor angiogenesis by blocking STAT3-mediated VEGF expression in human renal carcinoma cells. Carcinogenesis 2007, 28, 1780-1787. [CrossRef]

124. Yang, Y.; Li, Y.; Wang, K.; Wang, Y.; Yin, W.; Li, L. P38/NF-kB/snail pathway is involved in caffeic acid-induced inhibition of cancer stem cells-like properties and migratory capacity in malignant human keratinocyte. PLoS ONE 2013, 8, e58915. [CrossRef]

125. Kang, N.J.; Lee, K.W.; Shin, B.J.; Jung, S.K.; Hwang, M.K.; Bode, A.M.; Heo, Y.-S.; Lee, H.J.; Dong, Z. Caffeic acid, a phenolic phytochemical in coffee, directly inhibits Fyn kinase activity and UVB-induced COX-2 expression. Carcinogenesis 2009, 30, 321-330. [CrossRef]

126. Chao, P.-c.; Hsu, C.-c.; Yin, M.-c. Anti-inflammatory and anti-coagulatory activities of caffeic acid and ellagic acid in cardiac tissue of diabetic mice. Nutr. Metab. 2009, 6, 33. [CrossRef] [PubMed]

127. Khan, A.Q.; Khan, R.; Qamar, W.; Lateef, A.; Ali, F.; Tahir, M.; Sultana, S. Caffeic acid attenuates 12-O-tetradecanoyl-phorbol-13-acetate (TPA)-induced NF- $\mathrm{kB}$ and COX-2 expression in mouse skin: Abrogation of oxidative stress, inflammatory responses and proinflammatory cytokine production. Food Chem. Toxicol. 2012, 50, 175-183. [CrossRef] [PubMed]

128. Ghani, M.A.; Barril, C.; Bedgood, D.R.; Prenzler, P.D. Development of a method suitable for high-throughput screening to measure antioxidant activity in a linoleic acid emulsion. Antioxidants 2019, 8, 366. [CrossRef] [PubMed]

129. Guthrie, A.R.; Chow, H.H.S.; Martinez, J.A. Effects of resveratrol on drug-and carcinogen-metabolizing enzymes, implications for cancer prevention. Pharmacol. Res. Perspect. 2017, 5, e00294. [CrossRef] [PubMed]

130. Kowalczyk, M.C.; Kowalczyk, P.; Tolstykh, O.; Hanausek, M.; Walaszek, Z.; Slaga, T.J. Synergistic effects of combined phytochemicals and skin cancer prevention in SENCAR mice. Cancer Prev. Res. 2010, 3, 170-178. [CrossRef]

131. Yang, S.; Irani, K.; Heffron, S.E.; Jurnak, F.; Meyskens, F.L. Alterations in the expression of the apurinic/apyrimidinic endonuclease-1/redox factor-1 (APE/Ref-1) in human melanoma and identification of the therapeutic potential of resveratrol as an APE/Ref-1 inhibitor. Mol. Cancer Ther. 2005, 4, 1923-1935. [CrossRef]

132. Fuggetta, M.P.; D’Atri, S.; Lanzilli, G.; Tricarico, M.; Cannavò, E.; Zambruno, G.; Falchetti, R.; Ravagnan, G. In vitro antitumour activity of resveratrol in human melanoma cells sensitive or resistant to temozolomide. Melanoma Res. 2004, 14, 189-196. [CrossRef]

133. Zhang, X.; Liu, X.; Kang, S.; Liu, C.; Hao, Y. Resveratrol enhances the effects of ALA-PDT on skin squamous cells A431 through p38/MAPK signaling pathway. Cancer Biomark. 2018, 21, 797-803. [CrossRef]

134. Tyagi, A.; Gu, M.; Takahata, T.; Frederick, B.; Agarwal, C.; Siriwardana, S.; Agarwal, R.; Sclafani, R.A. Resveratrol selectively induces DNA Damage, independent of Smad4 expression, in its efficacy against human head and neck squamous cell carcinoma. Clin. Cancer Res. 2011, 17, 5402-5411. [CrossRef]

135. Kim, A.L.; Zhu, Y.; Zhu, H.; Han, L.; Kopelovich, L.; Bickers, D.R.; Athar, M. Resveratrol inhibits proliferation of human epidermoid carcinoma A431 cells by modulating MEK1 and AP-1 signalling pathways. Exp. Dermatol. 2006, 15, 538-546. [CrossRef]

136. Moyano-Mendez, J.R.; Fabbrocini, G.; De Stefano, D.; Mazzella, C.; Mayol, L.; Scognamiglio, I.; Carnuccio, R.; Ayala, F.; La Rotonda, M.I.; De Rosa, G. Enhanced antioxidant effect of trans-resveratrol: Potential of binary systems with polyethylene glycol and cyclodextrin. Drug Dev. Ind. Pharm. 2014, 40, 1300-1307. [CrossRef] [PubMed]

137. Shehzad, A.; Qureshi, M.; Anwar, M.N.; Lee, Y.S. Multifunctional curcumin mediate multitherapeutic effects. J. Food Sci. 2017, 82, 2006-2015. [CrossRef] [PubMed]

138. Lelli, D.; Sahebkar, A.; Johnston, T.P.; Pedone, C. Curcumin use in pulmonary diseases: State of the art and future perspectives. Pharmacol. Res. 2017, 115, 133-148. [CrossRef] [PubMed]

139. Kim, H.; Park, J.; Tak, K.-H.; Bu, S.Y.; Kim, E. Chemopreventive effects of curcumin on chemically induced mouse skin carcinogenesis in BK5. insulin-like growth factor-1 transgenic mice. In Vitro Cell. Dev. Biol. Anim. 2014, 50, 883-892. [CrossRef] 
140. Zhao, G.; Han, X.; Zheng, S.; Li, Z.; Sha, Y.; Ni, J.; Sun, Z.; Qiao, S.; Song, Z. Curcumin induces autophagy, inhibits proliferation and invasion by downregulating AKT/mTOR signaling pathway in human melanoma cells. Oncol. Rep. 2016, 35, 1065-1074. [CrossRef]

141. Wu, J.; Lu, W.-Y.; Cui, L.-L. Inhibitory effect of curcumin on invasion of skin squamous cell carcinoma A431 cells. Asian Pac. J. Cancer Prev. 2015, 16, 2813-2818. [CrossRef]

142. Qiu, Y.; Yu, T.; Wang, W.; Pan, K.; Shi, D.; Sun, H. Curcumin-induced melanoma cell death is associated with mitochondrial permeability transition pore (mPTP) opening. Biochem. Biophys. Res. Commun. 2014, 448, 15-21. [CrossRef]

143. Chinembiri, T.N.; Du Plessis, L.H.; Gerber, M.; Hamman, J.H.; Du Plessis, J. Review of natural compounds for potential skin cancer treatment. Molecules 2014, 19, 11679-11721. [CrossRef]

144. Iqbal, J.; Abbasi, B.A.; Ahmad, R.; Mahmood, T.; Kanwal, S.; Ali, B.; Khalil, A.T.; Shah, S.A.; Alam, M.M.; Badshah, H. Ursolic acid a promising candidate in the therapeutics of breast cancer: Current status and future implications. Biomed. Pharmacother. 2018, 108, 752-756. [CrossRef]

145. Shanmugam, M.K.; Dai, X.; Kumar, A.P.; Tan, B.K.; Sethi, G.; Bishayee, A. Ursolic acid in cancer prevention and treatment: Molecular targets, pharmacokinetics and clinical studies. Biochem. Pharmacol. 2013, 85, 1579-1587. [CrossRef]

146. Hsu, Y.-L.; Kuo, P.-L.; Lin, C.-C. Proliferative inhibition, cell-cycle dysregulation, and induction of apoptosis by ursolic acid in human non-small cell lung cancer A549 cells. Life Sci. 2004, 75, 2303-2316. [CrossRef] [PubMed]

147. Checker, R.; Sandur, S.K.; Sharma, D.; Patwardhan, R.S.; Jayakumar, S.; Kohli, V.; Sethi, G.; Aggarwal, B.B.; Sainis, K.B. Potent anti-inflammatory activity of ursolic acid, a triterpenoid antioxidant, is mediated through suppression of NF-kB, AP-1 and NF-AT. PLoS ONE 2012, 7, e31318. [CrossRef] [PubMed]

148. Ramachandran, S.; Prasad, N.R.; Pugalendi, K.; Menon, V. Modulation of UVB-induced oxidative stress by ursolic acid in human blood lymphocytes. Asian J. Biochem. 2010, 5, 173-180.

149. Moore, J.O.; Wang, Y.; Stebbins, W.G.; Gao, D.; Zhou, X.; Phelps, R.; Lebwohl, M.; Wei, H. Photoprotective effect of isoflavone genistein on ultraviolet B-induced pyrimidine dimer formation and PCNA expression in human reconstituted skin and its implications in dermatology and prevention of cutaneous carcinogenesis. Carcinogenesis 2006, 27, 1627-1635. [CrossRef] [PubMed]

150. Ji, C.; Yang, Y.-1.; He, L.; Gu, B.; Xia, J.-p.; Sun, W.-1.; Su, Z.-1.; Chen, B.; Bi, Z.-g. Increasing ceramides sensitizes genistein-induced melanoma cell apoptosis and growth inhibition. Biochem. Biophys. Res. Commun. 2012, 421, 462-467. [CrossRef]

151. Mazumder, M.A.R.; Hongsprabhas, P. Genistein as antioxidant and antibrowning agents in in vivo and in vitro: A review. Biomed. Pharmacother. 2016, 82, 379-392. [CrossRef]

152. Ng, C.Y.; Yen, H.; Hsiao, H.-Y.; Su, S.-C. Phytochemicals in skin cancer prevention and treatment: An updated review. Int. J. Mol. Sci. 2018, 19, 941. [CrossRef]

153. Iqbal, J.; Abbasi, B.A.; Ahmad, R.; Batool, R.; Mahmood, T.; Ali, B.; Khalil, A.T.; Kanwal, S.; Shah, S.A.; Alam, M.M. Potential phytochemicals in the fight against skin cancer: Current landscape and future perspectives. Biomed. Pharmacother. 2019, 109, 1381-1393. [CrossRef]

154. Sarkar, F.H.; Li, Y. Indole-3-carbinol and prostate cancer. J. Nutr. 2004, 134, 3493S-3498S. [CrossRef]

155. Rahman, K.W.; Aranha, O.; Glazyrin, A.; Chinni, S.R.; Sarkar, F.H. Translocation of Bax to mitochondria induces apoptotic cell death in indole-3-carbinol (I3C) treated breast cancer cells. Oncogene 2000, 19, 5764-5771. [CrossRef]

156. Choi, H.-S.; Cho, M.-C.; Lee, H.G.; Yoon, D.-Y. Indole-3-carbinol induces apoptosis through p53 and activation of caspase-8 pathway in lung cancer A549 cells. Food Chem. Toxicol. 2010, 48, 883-890. [CrossRef] [PubMed]

157. Christensen, J.G.; LeBlanc, G.A. Reversal of multidrug resistance in vivo by dietary administration of the phytochemical indole-3-carbinol. Cancer Res. 1996, 56, 574-581. [PubMed]

158. Wang, S.; Shen, P.; Zhou, J.; Lu, Y. Diet phytochemicals and cutaneous carcinoma chemoprevention: A review. Pharmacol. Res. 2017, 119, 327-346. [CrossRef] [PubMed]

159. Oyagbemi, A.; Saba, A.; Azeez, O. Capsaicin: A novel chemopreventive molecule and its underlying molecular mechanisms of action. Indian J. Cancer 2010, 47, 53. [CrossRef] [PubMed]

160. Iqbal, J.; Abbasi, B.A.; Mahmood, T.; Kanwal, S.; Ali, B.; Shah, S.A.; Khalil, A.T. Plant-derived anticancer agents: A green anticancer approach. Asian Pac. J. Trop. Biomed. 2017, 7, 1129-1150. [CrossRef] 
161. Montes de Oca, M.K.; Pearlman, R.L.; McClees, S.F.; Strickland, R.; Afaq, F. Phytochemicals for the prevention of photocarcinogenesis. Photochem. Photobiol. 2017, 93, 956-974. [CrossRef]

162. Tong, W.; Zhang, C.; Hong, T.; Liu, D.; Wang, C.; Li, J.; He, X.; Xu, W. Silibinin alleviates inflammation and induces apoptosis in human rheumatoid arthritis fibroblast-like synoviocytes and has a therapeutic effect on arthritis in rats. Sci. Rep. 2018, 8,1-12. [CrossRef]

163. Gu, M.; Singh, R.P.; Dhanalakshmi, S.; Agarwal, C.; Agarwal, R. Silibinin inhibits inflammatory and angiogenic attributes in photocarcinogenesis in SKH-1 hairless mice. Cancer Res. 2007, 67, 3483-3491. [CrossRef]

164. Katiyar, S.K.; Agarwal, R.; Wood, G.S.; Mukhtar, H. Inhibition of 12-O-tetradecanoylphorbol-13-acetate-caused tumor promotion in 7,12-dimethylbenz [a] anthracene-initiated SENCAR mouse skin by a polyphenolic fraction isolated from green tea. Cancer Res. 1992, 52, 6890-6897.

165. Katiyar, S.K.; Afaq, F.; Azizuddin, K.; Mukhtar, H. Inhibition of UVB-induced oxidative stress-mediated phosphorylation of mitogen-activated protein kinase signaling pathways in cultured human epidermal keratinocytes by green tea polyphenol (-)-epigallocatechin-3-gallate. Toxicol. Appl. Pharmacol. 2001, 176, 110-117. [CrossRef]

166. Ahmad, N.; Gupta, S.; Mukhtar, H. Green tea polyphenol epigallocatechin-3-gallate differentially modulates nuclear factor $\mathrm{kB}$ in cancer cells versus normal cells. Arch. Biochem. Biophys. 2000, 376, 338-346. [CrossRef] [PubMed]

167. Fujiki, H.; Watanabe, T.; Sueoka, E.; Rawangkan, A.; Suganuma, M. Cancer prevention with green tea and its principal constituent, EGCG: From early investigations to current focus on human cancer stem cells. Mol. Cells 2018, 41, 73 .

168. Kim, E.; Hwang, K.; Lee, J.; Han, S.Y.; Kim, E.-M.; Park, J.; Cho, J.Y. Skin protective effect of epigallocatechin gallate. Int. J. Mol. Sci. 2018, 19, 173. [CrossRef] [PubMed]

169. Miyata, Y.; Shida, Y.; Hakariya, T.; Sakai, H. Anti-cancer effects of green tea polyphenols against prostate cancer. Molecules 2019, 24, 193. [CrossRef] [PubMed]

170. Farrar, M.D.; Huq, R.; Mason, S.; Nicolaou, A.; Clarke, K.A.; Dew, T.P.; Williamson, G.; Watson, R.E.; Rhodes, L.E. Oral green tea catechins do not provide photoprotection from direct DNA damage induced by higher dose solar simulated radiation: A randomized controlled trial. J. Am. Acad. Dermatol. 2018, 78, 414-416. [CrossRef]

171. Bezerra, D.P.; Militão, G.C.G.; De Morais, M.C.; De Sousa, D.P. The dual antioxidant/prooxidant effect of eugenol and its action in cancer development and treatment. Nutrients 2017, 9, 1367. [CrossRef]

172. Xiang, D.; Wang, D.; He, Y.; Xie, J.; Zhong, Z.; Li, Z.; Xie, J. Caffeic acid phenethyl ester induces growth arrest and apoptosis of colon cancer cells via the $\beta$-catenin/T-cell factor signaling. Anti-Cancer Drugs 2006, 17, 753-762. [CrossRef]

173. Chen, M.-F.; Wu, C.-T.; Chen, Y.-J.; Keng, P.C.; Chen, W.-C. Cell killing and radiosensitization by caffeic acid phenethyl ester (CAPE) in lung cancer cells. J. Radiat. Res. 2004, 45, 253-260. [CrossRef]

174. Chen, M.-J.; Chang, W.-H.; Lin, C.-C.; Liu, C.-Y.; Wang, T.-E.; Chu, C.-H.; Shih, S.-C.; Chen, Y.-J. Caffeic acid phenethyl ester induces apoptosis of human pancreatic cancer cells involving caspase and mitochondrial dysfunction. Pancreatology 2008, 8, 566-576. [CrossRef]

175. Kuo, H.-C.; Kuo, W.-H.; Lee, Y.-J.; Lin, W.-L.; Chou, F.-P.; Tseng, T.-H. Inhibitory effect of caffeic acid phenethyl ester on the growth of C6 glioma cells in vitro and in vivo. Cancer Lett. 2006, 234, 199-208. [CrossRef]

176. Kudugunti, S.K.; Vad, N.M.; Ekogbo, E.; Moridani, M.Y. Efficacy of caffeic acid phenethyl ester (CAPE) in skin B16-F0 melanoma tumor bearing C57BL/6 mice. Investig. New Drugs 2011, 29, 52-62. [CrossRef] [PubMed]

177. Wu, J.; Horton, L.; Bosland, M.; Karkoszka, J.; Frenkel, K. Caffeic acid phenethyl ester (CAPE) as a preventive agent in preclinical model of breast cancer. In Proceedings of the AACR Annual Meeting, Los Angeles, CA, USA, 14-18 April 2007.

178. Chen, Y.-J.; Shiao, M.-S.; Hsu, M.-L.; Tsai, T.-H.; Wang, S.-Y. Effect of caffeic acid phenethyl ester, an antioxidant from propolis, on inducing apoptosis in human leukemic HL-60 cells. J. Agric. Food Chem. 2001, 49, 5615-5619. [CrossRef] [PubMed]

179. Yordanov, Y. Caffeic acid phenethyl ester (CAPE): Pharmacodynamics and potential for therapeutic application. Pharmacia 2019, 66, 107. [CrossRef] 
180. Ruan, J.-s.; Liu, Y.-p.; Zhang, L.; Yan, L.-g.; Fan, F.-t.; Shen, C.-s.; Wang, A.-y.; Zheng, S.-z.; Wang, S.-m.; $\mathrm{Lu}, \mathrm{Y}$. Luteolin reduces the invasive potential of malignant melanoma cells by targeting $\beta 3$ integrin and the epithelial-mesenchymal transition. Acta Pharmacol. Sin. 2012, 33, 1325-1331. [CrossRef]

181. Park, K.-K.; Chun, K.-S.; Lee, J.-M.; Lee, S.S.; Surh, Y.-J. Inhibitory effects of [6]-gingerol, a major pungent principle of ginger, on phorbol ester-induced inflammation, epidermal ornithine decarboxylase activity and skin tumor promotion in ICR mice. Cancer Lett. 1998, 129, 139-144. [CrossRef]

182. DeSalvo, K.B.; Olson, R.; Casavale, K.O. Dietary guidelines for Americans. JAMA 2016, 315, 457-458. [CrossRef]

183. Hussain, F.; Rana, Z.; Shafique, H.; Malik, A.; Hussain, Z. Phytopharmacological potential of different species of Morus alba and their bioactive phytochemicals: A review. Asian Pac. J. Trop. Biomed. 2017, 7, 950-956. [CrossRef]

184. Chaudhary, P.; Sharma, A.; Singh, B.; Nagpal, A.K. Bioactivities of phytochemicals present in tomato. J. Food Sci. Technol. 2018, 55, 2833-2849. [CrossRef]

185. Cavazos-Garduño, A.; Serrano-Niño, J.C.; García-Varela, R.; García, H.S. Anticarcinogenic phytochemicals. Fruit Veg. Phytochem. Chem. Hum. Health 2017, 2, 53-66.

186. Singh, C.K.; Siddiqui, I.A.; El-Abd, S.; Mukhtar, H.; Ahmad, N. Combination chemoprevention with grape antioxidants. Mol. Nutr. Food Res. 2016, 60, 1406-1415. [CrossRef]

187. Vinson, J.A.; Su, X.; Zubik, L.; Bose, P. Phenol antioxidant quantity and quality in foods: Fruits. J. Agric. Food Chem. 2001, 49, 5315-5321. [CrossRef] [PubMed]

188. Wolfe, K.; Wu, X.; Liu, R.H. Antioxidant activity of apple peels. J. Agric. Food Chem. 2003, 51, 609-614. [CrossRef] [PubMed]

189. Ding, M.; Lu, Y.; Bowman, L.; Huang, C.; Leonard, S.; Wang, L.; Vallyathan, V.; Castranova, V.; Shi, X. Inhibition of AP-1 and neoplastic transformation by fresh apple peel extract. J. Biol. Chem. 2004, 279, 10670-10676. [CrossRef] [PubMed]

190. George, V.C.; Rupasinghe, H. Apple flavonoids suppress carcinogen-induced DNA damage in normal human bronchial epithelial cells. Oxidative Med. Cell. Longev. 2017, 2017, 1-12. [CrossRef] [PubMed]

191. Li, C.X.; Zhao, X.H.; Zuo, W.F.; Zhang, T.L.; Zhang, Z.Y.; Chen, X.S. Phytochemical profiles, antioxidant, and antiproliferative activities of four red-fleshed apple varieties in China. J. Food Sci. 2020, 85, 718-726. [CrossRef]

192. Zaid, M.A.; Afaq, F.; Syed, D.N.; Dreher, M.; Mukhtar, H. Inhibition of UVB-mediated oxidative stress and markers of photoaging in immortalized HaCaT keratinocytes by pomegranate polyphenol extract POMx. Photochem. Photobiol. 2007, 83, 882-888. [CrossRef]

193. Türkyılmaz, M.; Hamzaoğlu, F.; Özkan, M. Combined use of hydrocolloids in pomegranate juice and their effects on clarification and copigmentation. Int. J. Food Sci. Technol. 2020, 55, 1426-1436. [CrossRef]

194. Afaq, F.; Zaid, M.A.; Khan, N.; Dreher, M.; Mukhtar, H. Protective effect of pomegranate-derived products on UVB-mediated damage in human reconstituted skin. Exp. Dermatol. 2009, 18, 553-561. [CrossRef]

195. Perde-Schrepler, M.; Chereches, G.; Brie, I.; Tatomir, C.; Postescu, I.D.; Soran, L.; Filip, A. Grape seed extract as photochemopreventive agent against UVB-induced skin cancer. J. Photochem. Photobiol. B Biol. 2013, 118, 16-21. [CrossRef]

196. Pedro, A.C.; Maciel, G.M.; Rampazzo Ribeiro, V.; Haminiuk, C.W.I. Fundamental and applied aspects of catechins from different sources: A review. Int. J. Food Sci. Technol. 2020, 55, 429-442. [CrossRef]

197. Kalekhan, F.; Bala, N.; Rao, S.; Pais, M.L.; Adnan, M.; Sajan, S.; Baliga, M.S. Usefulness of grape seed polyphenols in the prevention of skin cancer: A mini review. In Functional Foods in Cancer Prevention and Therapy; Elsevier: Amsterdam, The Netherlands, 2020; pp. 159-167.

198. Afaq, F.; Saleem, M.; Krueger, C.G.; Reed, J.D.; Mukhtar, H. Anthocyanin-and hydrolyzable tannin-rich pomegranate fruit extract modulates MAPK and NF- $\kappa B$ pathways and inhibits skin tumorigenesis in CD-1 mice. Int. J. Cancer 2005, 113, 423-433. [CrossRef] [PubMed]

199. Hora, J.J.; Maydew, E.R.; Lansky, E.P.; Dwivedi, C. Chemopreventive effects of pomegranate seed oil on skin tumor development in CD1 mice. J. Med. Food 2003, 6, 157-161. [CrossRef] [PubMed]

200. Afaq, F.; Khan, N.; Syed, D.N.; Mukhtar, H. Oral feeding of pomegranate fruit extract inhibits early biomarkers of UVB radiation-induced carcinogenesis in SKH-1 hairless mouse epidermis. Photochem. Photobiol. 2010, 86, 1318-1326. [CrossRef] [PubMed] 
201. Khan, N.; Syed, D.N.; Pal, H.C.; Mukhtar, H.; Afaq, F. Pomegranate fruit extract inhibits UVB-induced inflammation and proliferation by modulating NF-KB and MAPK signaling pathways in mouse skin. Photochem. Photobiol. 2012, 88, 1126-1134. [CrossRef] [PubMed]

202. Kopec, R.E.; Schick, J.; Tober, K.L.; Riedl, K.M.; Francis, D.M.; Young, G.S.; Schwartz, S.J.; Oberyszyn, T.M. Sex differences in skin carotenoid deposition and acute UVB-induced skin damage in SKH-1 hairless mice after consumption of tangerine tomatoes. Mol. Nutr. Food Res. 2015, 59, 2491-2501. [CrossRef] [PubMed]

203. Tanambell, H.; Bishop, K.S.; Quek, S.Y. Tangerine tomatoes: Origin, biochemistry, potential health benefits and future prospects. Crit. Rev. Food Sci. Nutr. 2020, 1-12. [CrossRef]

204. Guerra, K.C.; Crane, J.S. Skin cancer prevention. In StatPearls; StatPearls Publishing: Treasure Island, FL, USA, 2020.

205. Cooperstone, J.L.; Tober, K.L.; Riedl, K.M.; Teegarden, M.D.; Cichon, M.J.; Francis, D.M.; Schwartz, S.J.; Oberyszyn, T.M. Tomatoes protect against development of UV-induced keratinocyte carcinoma via metabolomic alterations. Sci. Rep. 2017, 7, 1-9. [CrossRef]

206. Cho, B.O.; Che, D.N.; Shin, J.Y.; Kang, H.J.; Jang, S.I. Ameliorative effects of fruit stem extract from Muscat Bailey A against chronic UV-induced skin damage in BALB/c mice. Biomed. Pharmacother. 2018, 97, 1680-1688. [CrossRef]

207. Nieto, J.A.; Santoyo, S.; Prodanov, M.; Reglero, G.; Jaime, L. Valorisation of Grape Stems as a Source of Phenolic Antioxidants by Using a Sustainable Extraction Methodology. Foods 2020, 9, 604. [CrossRef]

208. Lucarini, M.; Durazzo, A.; Kiefer, J.; Santini, A.; Lombardi-Boccia, G.; Souto, E.B.; Romani, A.; Lampe, A.; Ferrari Nicoli, S.; Gabrielli, P. Grape seeds: Chromatographic profile of fatty acids and phenolic compounds and qualitative analysis by FTIR-ATR spectroscopy. Foods 2020, 9, 10. [CrossRef]

209. Armstrong, B.K.; Kricker, A. The epidemiology of UV induced skin cancer. J. Photochem. Photobiol. B Biol. 2001, 63, 8-18. [CrossRef]

210. Hanausek, M.; Spears, E.; Walaszek, Z.; Kowalczyk, M.C.; Kowalczyk, P.; Wendel, C.; Slaga, T.J. Inhibition of murine skin carcinogenesis by freeze-dried grape powder and other grape-derived major antioxidants. Nutr. Cancer 2011, 63, 28-38. [CrossRef] [PubMed]

211. Gil, M.I.; Tomás-Barberán, F.A.; Hess-Pierce, B.; Holcroft, D.M.; Kader, A.A. Antioxidant activity of pomegranate juice and its relationship with phenolic composition and processing. J. Agric. Food Chem. 2000, 48, 4581-4589. [CrossRef] [PubMed]

212. Afaq, F.; Malik, A.; Syed, D.; Maes, D.; Matsui, M.S.; Mukhtar, H. Pomegranate Fruit Extract Modulates UV-B-mediated Phosphorylation of Mitogen-activated Protein Kinases and Activation of Nuclear Factor Kappa B in Normal Human Epidermal Keratinocytes. Photochem. Photobiol. 2005, 81, 38-45. [CrossRef] [PubMed]

213. Di Mascio, P.; Kaiser, S.; Sies, H. Lycopene as the most efficient biological carotenoid singlet oxygen quencher. Arch. Biochem. Biophys. 1989, 274, 532-538. [CrossRef]

214. Stahl, W.; Heinrich, U.; Aust, O.; Tronnier, H.; Sies, H. Lycopene-rich products and dietary photoprotection. Photochem. Photobiol. Sci. 2006, 5, 238-242. [CrossRef]

215. Filip, A.; Daicoviciu, D.; Clichici, S.; Mocan, T.; Muresan, A.; Postescu, I.D. Photoprotective Effects of Two Natural Products on Ultraviolet B-Induced Oxidative Stress and Apoptosis in SKH-1 Mouse Skin. J. Med. Food 2011, 14, 761-766. [CrossRef] [PubMed]

216. Filip, A.; Daicoviciu, D.; Clichici, S.; Bolfa, P.; Catoi, C.; Baldea, I.; Bolojan, L.; Olteanu, D.; Muresan, A.; Postescu, I. The effects of grape seeds polyphenols on SKH-1 mice skin irradiated with multiple doses of UV-B. J. Photochem. Photobiol. B Biol. 2011, 105, 133-142. [CrossRef]

217. Che, D.N.; Xie, G.H.; Cho, B.O.; Shin, J.Y.; Kang, H.J.; Jang, S.I. Protective effects of grape stem extract against UVB-induced damage in C57BL mice skin. J. Photochem. Photobiol. B Biol. 2017, 173, 551-559. [CrossRef]

218. Arimoto-Kobayashi, S.; Zhang, X.; Yuhara, Y.; Kamiya, T.; Negishi, T.; Okamoto, G. Chemopreventive effects of the juice of Vitis coignetiae Pulliat on two-stage mouse skin carcinogenesis. Nutr. Cancer 2013, 65, 440-450. [CrossRef]

219. Sharma, S.D.; Katiyar, S.K. Dietary grape seed proanthocyanidins inhibit UVB-induced cyclooxygenase-2 expression and other inflammatory mediators in UVB-exposed skin and skin tumors of SKH-1 hairless mice. Pharm. Res. 2010, 27, 1092-1102. [CrossRef] [PubMed] 
220. Singh, C.K.; Mintie, C.A.; Ndiaye, M.A.; Chhabra, G.; Dakup, P.P.; Ye, T.; Yu, M.; Ahmad, N. Chemoprotective effects of dietary grape powder on UVB radiation-mediated skin carcinogenesis in SKH-1 hairless mice. J. Investig. Dermatol. 2019, 139, 552-561. [CrossRef] [PubMed]

221. Stylos, E.; Chatziathanasiadou, M.V.; Syriopoulou, A.; Tzakos, A.G. Liquid chromatography coupled with tandem mass spectrometry (LC-MS/MS) based bioavailability determination of the major classes of phytochemicals. J. Chromatogr. B 2017, 1047, 15-38. [CrossRef] [PubMed]

222. Krupkova, O.; Ferguson, S.J.; Wuertz-Kozak, K. Stability of (-)-epigallocatechin gallate and its activity in liquid formulations and delivery systems. J. Nutr. Biochem. 2016, 37, 1-12. [CrossRef] [PubMed]

223. Iqbal, J.; Abbasi, B.A.; Ahmad, R.; Mahmood, T.; Ali, B.; Khalil, A.T.; Kanwal, S.; Shah, S.A.; Alam, M.M.; Badshah, H. Nanomedicines for developing cancer nanotherapeutics: From benchtop to bedside and beyond. Appl. Microbiol. Biotechnol. 2018, 102, 9449-9470. [CrossRef]

224. Yadav, R.; Kumar, D.; Kumari, A.; Yadav, S.K. Encapsulation of catechin and epicatechin on BSA NPs improved their stability and antioxidant potential. EXCLI J. 2014, 13, 331.

225. Ahmad, A.; Li, Y.; Sarkar, F.H. The bounty of nature for changing the cancer landscape. Mol. Nutr. Food Res. 2016, 60, 1251-1263. [CrossRef]

226. Subramanian, A.; Jaganathan, S.; Manikandan, A.; Pandiaraj, K.; Gomathi, N.; Supriyanto, E. Recent trends in nano-based drug delivery systems for efficient delivery of phytochemicals in chemotherapy. RSC Adv. 2016, 6, 48294-48314. [CrossRef]

227. Chikara, S.; Nagaprashantha, L.D.; Singhal, J.; Horne, D.; Awasthi, S.; Singhal, S.S. Oxidative stress and dietary phytochemicals: Role in cancer chemoprevention and treatment. Cancer Lett. 2018, 413, 122-134. [CrossRef]

228. Afrin, S.; Giampieri, F.; Gasparrini, M.; Forbes-Hernández, T.Y.; Cianciosi, D.; Reboredo-Rodriguez, P.; Zhang, J.; Manna, P.P.; Daglia, M.; Atanasov, A.G. Dietary phytochemicals in colorectal cancer prevention and treatment: A focus on the molecular mechanisms involved. Biotechnol. Adv. 2020, 38, 107322. [CrossRef]

(C) 2020 by the authors. Licensee MDPI, Basel, Switzerland. This article is an open access article distributed under the terms and conditions of the Creative Commons Attribution (CC BY) license (http://creativecommons.org/licenses/by/4.0/). 